\title{
Development of the drop Freezing Ice Nuclei Counter (FINC), intercomparison of droplet freezing techniques, and use of soluble lignin as an atmospheric ice nucleation standard
}

\author{
Anna J. Miller ${ }^{1} \star$, Killian P. Brennan ${ }^{2} \star$, Claudia Mignani ${ }^{3}$, Jörg Wieder ${ }^{2}$, Robert O. David ${ }^{4}$, and \\ Nadine Borduas-Dedekind ${ }^{1,2, a}$ \\ ${ }^{1}$ Institute for Biogeochemistry and Pollutant Dynamics, ETH Zurich, Zurich, 8092 Switzerland \\ ${ }^{2}$ Institute for Atmospheric and Climate Science, ETH Zurich, Zurich, 8092 Switzerland \\ ${ }^{3}$ Department of Environmental Sciences, University of Basel, Basel, 4056 Switzerland \\ ${ }^{4}$ Department of Geosciences, University of Oslo, Oslo, 0315 Norway \\ anow at: Department of Chemistry, University of British Columbia, Vancouver, V6T 1Z1, Canada \\ These authors contributed equally to this work.
}

Correspondence: Nadine Borduas-Dedekind (borduas@chem.ubc.ca)

Received: 16 October 2020 - Discussion started: 11 November 2020

Revised: 12 February 2021 - Accepted: 15 February 202 - Published: 28 April 2021

\begin{abstract}
Aerosol-cloud interactions, including the ice nucleation of supercooled liquid water droplets caused by icenucleating particles (INPs) and macromolecules (INMs), are a source of uncertainty in predicting future climate. Because INPs and INMs have spatial and temporal heterogeneity in source, number, and composition, predicting their concentration and distribution is a challenge requiring apt analytical instrumentation. Here, we present the development of our drop Freezing Ice Nuclei Counter (FINC) for the estimation of INP and INM concentrations in the immersion freezing mode. FINC's design builds upon previous droplet freezing techniques (DFTs) and uses an ethanol bath to cool sample aliquots while detecting freezing using a camera. Specifically, FINC uses 288 sample wells of 5-60 $\mu \mathrm{L}$ volume, has a limit of detection of $-25.4 \pm 0.2^{\circ} \mathrm{C}$ with $5 \mu \mathrm{L}$, and has an instrument temperature uncertainty of $\pm 0.5^{\circ} \mathrm{C}$. We further conducted freezing control experiments to quantify the nonhomogeneous behavior of our developed DFT, including the consideration of eight different sources of contamination.

As part of the validation of FINC, an intercomparison campaign was conducted using an NX-illite suspension and an ambient aerosol sample from two other drop freezing instruments: ETH's DRoplet Ice Nuclei Counter Zurich (DRINCZ) and the University of Basel's LED-based Ice Nucleation Detection Apparatus (LINDA). We also tabulated an
\end{abstract}

exhaustive list of peer-reviewed DFTs, to which we added our characterized and validated FINC.

In addition, we propose herein the use of a water-soluble biopolymer, lignin, as a suitable ice-nucleating standard. An ideal INM standard should be inexpensive, accessible, reproducible, unaffected by sample preparation, and consistent across techniques. First, we compared lignin's freezing temperature across different drop freezing instruments, including on DRINCZ and LINDA, and then determined an empirical fit parameter for future drop freezing validations. Subsequently, we showed that commercial lignin has consistent ice-nucleating activity across product batches and demonstrated that the ice-nucleating ability of aqueous lignin solutions is stable over time. With these findings, we present lignin as a good immersion freezing standard for future DFT intercomparisons in the research field of atmospheric ice nucleation.

\section{Introduction}

Aerosol-cloud interactions are a source of uncertainty in predicting future radiative forcing (IPCC, 2013). One important aerosol-cloud interaction is the ice nucleation of supercooled liquid water droplets caused by ice-nucleating 
particles (INPs). Heterogeneous freezing can occur at temperatures as warm as $-1^{\circ} \mathrm{C}$ for certain bacterial (e.g., $P$. syringae; Morris et al., 2004) and fungal (e.g., Fusarium species; Richard et al., 1996) INPs as well as for other currently unidentified warm INPs (Lloyd et al., 2020). INPs typically include solid surfaces such as dust and cellular material, which template ice, but recently reported ice-nucleating macromolecules (INMs) are also capable of freezing supercooled water droplets (e.g., Pummer et al., 2012, 2015; Felgitsch et al., 2018; Kunert et al., 2019). INMs are defined here as operationally dissolved organic matter passing through a $0.2 \mu \mathrm{L}$ filter (Borduas-Dedekind et al., 2019). In the absence of INPs and INMs, cloud droplets with an average radius of $10 \mu \mathrm{m}$ remain liquid until instantaneous $(<1 \mathrm{~s})$ homogeneous nucleation at approximately $-38^{\circ} \mathrm{C}$ (Koop and Murray, 2016; Kanji et al., 2017). The immersion freezing mode dominates heterogeneous freezing in mixed-phase clouds (Hoose et al., 2010; de Boer et al., 2011; Murray et al., 2012; Westbrook and Illingworth, 2013; Tobo, 2016; Kanji et al., 2017) and occurs when an INP or an INM nucleates ice from within a supercooled water droplet (Storelvmo, 2017; Vali et al., 2015). For instance, Hoose et al. (2010) reported that more than $85 \%$ of heterogeneous freezing events in their simulation occurred via the immersion mode. Following ice nucleation, the ice crystal concentration in mixedphase clouds can rapidly increase through secondary ice processes, affecting the ratio of liquid water to ice crystals. This ratio impacts cloud microphysics and thus the lifetime, optical density, and radiative properties of clouds, thereby impacting the hydrological cycle and climate (Lohmann et al., 2016; Storelvmo, 2017; Zhao et al., 2019). Indeed, Heymsfield et al. (2020) recently reported that up to $77 \%$ of global surface precipitation originates from the ice phase. Thus, the ability to predict INP and INM concentrations can improve estimates of primary and secondary ice concentrations in mixed-phase clouds and thus help reduce uncertainties in weather and climate projections (Murray et al., 2021).

This prediction is challenging due to spatial and temporal heterogeneity in the source, number, and composition of INPs and INMs. In order to reduce uncertainties, advanced methods are needed to quantify and characterize INPs and INMs from ambient and laboratory samples. A variety of laboratory instruments has been developed to measure INPs in the immersion freezing mode. Methods include continuousflow diffusion chambers (e.g., Rogers, 1988), single-particle levitation apparatuses (e.g., Diehl et al., 2014), and bench-top droplet freezing techniques (DFTs) (e.g., Hill et al., 2014). Bench-top methods vary in terms of many variables, including cooling method, droplet generation, droplet size, droplet number, freezing detection method, detectable freezing temperature ranges, and measurement uncertainties. Cooling methods typically use either a cold stage (e.g., Wright and Petters, 2013; O'Sullivan et al., 2014; Budke and Koop, 2015; Tobo, 2016; Chen et al., 2018b, a; Häusler et al., 2018; Mignani et al., 2019; Tarn et al., 2020), a block cooled with liquid refrigerant (e.g., Hill et al., 2014; Kunert et al., 2018; Steinke et al., 2020), or a liquid cooling bath (e.g., Stopelli et al., 2014; Beall et al., 2017; Chen et al., 2018b; David et al., 2019; Gute and Abbatt, 2020). Droplet generation includes micropipetting (e.g., Hill et al., 2014; Chen et al., 2018a; David et al., 2019), shaking a vial to make an emulsion (e.g., Pummer et al., 2012; Wright and Petters, 2013), piezo-driven droplet generation (e.g., Peckhaus et al., 2016), microfluidic flow-focusing droplet generation (e.g., Stan et al., 2009; Reicher et al., 2018; Brubaker et al., 2020; Tarn et al., 2020), and filled cavities on a chip (Häusler et al., 2018). Droplet sizes and numbers vary by generation method; pipetting typically produces fewer microliter-sized drops and microfluidic devices produce a larger number of nanoliter-sized droplets. Droplets can be placed either on plates coated in a hydrophobic substance such as petroleum jelly or in plastic wells such as within a multiwell polymerase chain reaction (PCR) tray. Freezing can be optically detected by manual visual inspection (e.g., Creamean et al., 2018; Hill et al., 2014), with software to detect freezing optically (e.g., Stopelli et al., 2014; David et al., 2019; Perkins et al., 2020; Gute and Abbatt, 2020), with pyroelectrics (e.g., Cook et al., 2020), or by infrared thermal detection (e.g., Zaragotas et al., 2016; Harrison et al., 2018; Kunert et al., 2018).

Each bench-top immersion freezing method has its advantages and disadvantages, which vary depending on the samples of interest. Herein, we compiled a summary of multidrop bench-top immersion freezing instruments used for atmospheric ice nucleation measurements published between 2000 and 2020 (Table 1). Included in this summary is a brief description of the operation of each instrument, the water background with the reported protocol, the average drop size, and the average number of droplets per experiment. Generally, advantageous qualities include large operating temperature ranges, low background freezing temperatures, and a high number of drops per experiment. As these types of instruments are not yet commercial, we also built our own drop Freezing Ice Nuclei Counter (FINC) using a cooling bath and an optical detection method. In comparison to the existing methods, FINC fits well within the range of operating parameters with drop sizes of 5-60 $\mu \mathrm{L}, 288$ drops per experiment, and background freezing at $-25^{\circ} \mathrm{C}$ (Table 1). Noteworthy features of FINC compared to existing methods are its automation of the ethanol level, its use of 288 wells to increase statistics, and its improved code for well detection and for harmonizing the output data.

With an increasing number of research groups developing DFTs, there is an ongoing search for suitable standards for freezing temperature intercomparisons. A typical standard used to compare immersion freezing instruments is the mineral dust NX-illite, a known ice-active mineral and a cheap and readily available material (Hiranuma et al., 2015a). However, NX-illite measurements can differ by orders of magnitude across different instruments (Hiranuma et al., 2015a). This discrepancy may be due to NX-illite's insolubility in 

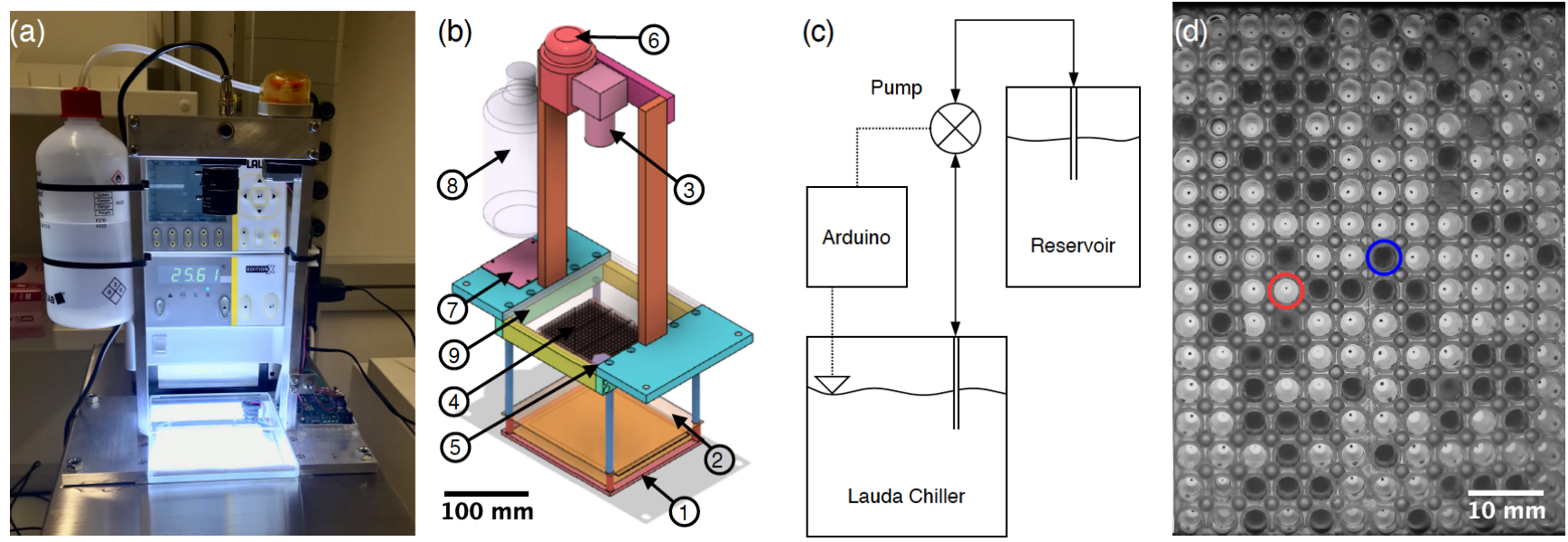

Figure 1. (a) Photograph of FINC. (b) Computer-aided design (CAD) software model of the aluminum and stainless-steel movable structure placed inside the LAUDA bath. The circled numbers correspond to the following parts: (1) a chip-on-board LED array, (2) a thin polytetrafluoroethylene sheet, (3) a camera, (4) three clear polypropylene Piko ${ }^{\mathrm{TM}}$ PCR trays, (5) a level sensor, (6) a peristaltic pump, (7) an Arduino board and a stepper motor driver, (8) an ethanol reservoir, and (9) a Plexiglas plate. (c) Flowchart of the bath leveler setup. (d) Image of two of the three trays taken by the FINC camera showing the difference in light intensity between the liquid (circled in red) and frozen (circled in blue) wells used for freezing temperature detection.

water, creating a suspension rather than a homogeneous solution. In practice, NX-illite suspensions settle quickly, potentially leading to a range of freezing temperatures. Cellulose has also been used as an intercomparison standard (Hiranuma et al., 2019), as it is the most abundant biopolymer in the environment and can contribute to ice nucleation in clouds below about $-21^{\circ} \mathrm{C}$ (Hiranuma et al., 2015b). However, cellulose is also a suspension in water. Snomax ${ }^{\circledR}$ has additionally been used as a bacterial ice-nucleating standard and consists of freeze-dried, irradiated cells from $P$. syringae (Wex et al., 2015). Unfortunately, Polen et al. (2016) found that solutions of Snomax can have irreproducible ice-nucleating activity over time, making it a rather poor standard.

An alternative to mineral dust, cellulose, and Snomax is the use of a water-soluble organic material as a standard in immersion freezing experiments. Here, we show that commercial lignin, a complex organic polymer from the cell wall structure of vascular plants (Ciesielski et al., 2020), can serve as a reproducible standard for ice nucleation across different immersion freezing techniques. Indeed, lignin is a watersoluble macromolecule with ice-nucleating activity, thereby qualifying it as an INM (Pummer et al., 2015; Bogler and Borduas-Dedekind, 2020; Steinke et al., 2020). Furthermore, lignin and its oxidation products are present in the atmosphere and are emitted, for example, during agricultural harvesting and biomass burning in Houston, Texas, with typical plume concentrations of $149 \mathrm{ng} \mathrm{m}^{-3}$ (Myers-Pigg et al., 2016; Shakya et al., 2011). Lignin is also produced as a by-product of an industrial process in which wood is converted to wood pulp and subsequently used for paper products (Harkin, 1969). Recent research has shown lignin to be ice-active, albeit with colder freezing temperatures than leaf litter and agricultural dust (Steinke et al., 2020; Bogler and Borduas-Dedekind, 2020). Several other studies have shown that plant materials, which may have included lignin, can be ice-active in immersion freezing (e.g., Conen et al., 2016; Felgitsch et al., 2018; Suski et al., 2018; Gute and Abbatt, 2020).

Herein, we present (1) the development, characterization, and validation of our home-built FINC for the quantification of INP and INM concentrations in the immersion freezing mode, (2) an intercomparison of DFTs to validate FINC, and (3) the use of soluble lignin as an intercomparison standard. As part of our intercomparison study with lignin, we show results with two other drop freezing instruments: ETH Zurich's DRoplet Ice Nuclei Counter Zurich (DRINCZ; David et al., 2019) and the University of Basel's LED-based Ice Nucleation Detection Apparatus (LINDA; Stopelli et al., 2014). We conclude by recommending commercial lignin as a standard to validate DFTs based on a detailed analysis of lignin's reproducibility and stable IN activity.

\section{Instrument development}

\subsection{Building components}

\subsubsection{Hardware}

The hardware design of FINC is based on DRINCZ (David et al., 2019), its predecessors (Stopelli et al., 2014; Hill et al., 2014), and earlier descriptions of water droplets placed on oil-covered aluminum sheets over a cold plate, as described, for example, in Vali and Stansbury (1966) and Vali (1995). FINC has a temperature-controlled ethanol cooling 
Table 1. List of droplet freezing techniques (DFTs) ordered by year of first publication. Information includes the instrument name, a brief description of the instrument, the freezing temperature of a water background freezing experiment according to the reported protocol (median where available), the droplet size used, the number of droplets per experiment (drops/expt.), and the main references associated with the instrument, including the reference in which the instrument was first published and, if applicable, a following reference with updates; "n.f." indicates information not found.

\begin{tabular}{|c|c|c|c|c|c|}
\hline Instrument name & Brief description & $\begin{array}{l}\text { Water background } \\
\text { using reported } \\
\text { protocol }\left({ }^{\circ} \mathrm{C}\right)\end{array}$ & Drop size & Drops/expt. & References \\
\hline $\begin{array}{l}\text { Flow cell microscopy tech- } \\
\text { nique for aerosol phase tran- } \\
\text { sitions }\end{array}$ & $\begin{array}{l}\text { Vapors condensed onto the bottom of a } \\
\text { sample cell on aluminum cooling block; } \\
\text { freezing monitored via microscope }\end{array}$ & -37 & $7-33 \mu \mathrm{m}$ diam. & $\sim 65$ & $\begin{array}{l}\text { Salcedo et al. (2000), } \\
\text { Koop et al. (2000a) }\end{array}$ \\
\hline $\begin{array}{l}\text { Droplet freezing technique } \\
\text { (DFT) }\end{array}$ & $\begin{array}{l}\text { Particles deposited on a glass slide in } \\
\text { a sample cell on a cold stage, with } \\
\text { droplets grown by water vapor; freezing } \\
\text { monitored via microscope }\end{array}$ & -37 & $120 \mu \mathrm{m}$ diam. & $<100$ & $\begin{array}{l}\text { Dymarska et al. (2006), } \\
\text { Mason et al. (2015) }\end{array}$ \\
\hline Microfluidic apparatus & $\begin{array}{l}\text { Flow-focusing nozzle continuously } \\
\text { produces droplets in a stream of fluo- } \\
\text { rocarbon across a seven-temperature- } \\
\text { zone cold plate; freezing monitored via } \\
\text { microscope }\end{array}$ & -37 & $80 \mu \mathrm{m}$ diam. & $>10000$ & Stan et al. (2009) \\
\hline $\begin{array}{l}\text { FRankfurt Ice Deposition } \\
\text { freezinG Experiment }- \text { Tel } \\
\text { Aviv University (FRIDGE- } \\
\text { TAU) }\end{array}$ & $\begin{array}{l}\text { Pipetted drops onto Vaseline-coated } \\
\text { Peltier cold stage in low-pressure dif- } \\
\text { fusion chamber; freezing monitored via } \\
\text { CCD camera }\end{array}$ & -35 & $2 \mu \mathrm{L}$ & $\sim 120$ & $\begin{array}{l}\text { Bundke et al. (2008), } \\
\text { Ardon-Dryer et al. (2011) }\end{array}$ \\
\hline $\begin{array}{l}\text { Picoliter and Nanoliter Nu- } \\
\text { cleation by Immersed Particle } \\
\text { Instrument (pico-NIPI, nano- } \\
\text { NIPI) }\end{array}$ & $\begin{array}{l}\text { Nebulized droplets encased in silicon } \\
\text { oil on hydrophobic glass slides on alu- } \\
\text { minum cold stage; freezing monitored } \\
\text { via microscope }\end{array}$ & -37 & $\begin{array}{l}0.25-1.7 \mathrm{pL} \\
0.1-6 \mathrm{~nL}\end{array}$ & $\begin{array}{l}\sim 135(\mathrm{pL}) \\
\sim 51(\mathrm{~nL})\end{array}$ & $\begin{array}{l}\text { Murray et al. (2010), } \\
\text { O'Sullivan et al. (2014), }\end{array}$ \\
\hline $\begin{array}{l}\text { Vienna Optical Droplet Crys- } \\
\text { tallization Analyzer } \\
\text { (VODCA) }\end{array}$ & $\begin{array}{l}\text { Water-oil emulsion pipetted onto a } \\
\text { glass slide on a Peltier cold stage, all } \\
\text { contained in an airtight cell; freezing } \\
\text { monitored via microscope }\end{array}$ & -36 & $\begin{array}{l}10-200 \mu \mathrm{m} \\
\text { diam. }\end{array}$ & n.f. & Pummer et al. (2012) \\
\hline $\begin{array}{l}\text { Drop freezing apparatus for } \\
\text { filters }\end{array}$ & $\begin{array}{l}\text { Filter cutouts placed inside small tubes } \\
\text { with water, cooled in a water bath; } \\
\text { freezing monitored by manual inspec- } \\
\text { tion }\end{array}$ & -12 & $0.1 \mathrm{~mL}$ & 108 & Conen et al. (2012) \\
\hline $\begin{array}{l}\text { Microliter Nucleation by Im- } \\
\text { mersed Particle Instrument } \\
\text { (microL-NIPI) }\end{array}$ & $\begin{array}{l}\text { Drops pipetted onto a hydrophobic } \\
\text { glass slide in humidity-controlled en- } \\
\text { closure on a cold stage; freezing mon- } \\
\text { itored via camera }\end{array}$ & -26 & $1 \mu \mathrm{L}$ & 40 & $\begin{array}{l}\text { Atkinson et al. (2013), } \\
\text { Whale et al. (2015) }\end{array}$ \\
\hline $\begin{array}{l}\text { North Carolina State Univer- } \\
\text { sity cold stage (NC State-CS) }\end{array}$ & $\begin{array}{l}\text { Emulsion of water in squalene placed } \\
\text { on a glass slide resting in an aluminum } \\
\text { dish on a thermoelectric element; freez- } \\
\text { ing monitored via camera }\end{array}$ & -34 to -36 & $400 \mathrm{pL}-150 \mathrm{~nL}$ & $300-1500$ & $\begin{array}{l}\text { Wright et al. (2013), } \\
\text { Hiranuma et al. (2015a) }\end{array}$ \\
\hline $\begin{array}{l}\text { Microfluidic device for homo- } \\
\text { geneous ice nucleation }\end{array}$ & $\begin{array}{l}\text { Microfluidically produced water-in-oil } \\
\text { emulsion on cryo-microscopy cold } \\
\text { stage; freezing monitored via micro- } \\
\text { scope (alternatively frozen with differ- } \\
\text { ential scanning calorimetry) }\end{array}$ & -36 to -37 & $\begin{array}{l}53-96 \mu \mathrm{m} \\
\text { diam. }\end{array}$ & $>1000$ & Riechers et al. (2013) \\
\hline $\begin{array}{l}\text { LED-based Ice Nucleation } \\
\text { Detection Apparatus } \\
\text { (LINDA) }\end{array}$ & $\begin{array}{l}\text { Sample in tubes held in polycarbonate } \\
\text { tray atop an LED array submersed in } \\
\text { a water-glycerin cooling bath; freezing } \\
\text { monitored via camera }\end{array}$ & -15 & $40-400 \mu \mathrm{L}$ & 52 & Stopelli et al. (2014) \\
\hline $\begin{array}{l}\text { Colorado State University Ice } \\
\text { Spectrometer (CSU-IS) }\end{array}$ & $\begin{array}{l}\text { Sample aliquots pipetted into two } 96- \\
\text { well PCR trays cooled on custom cold } \\
\text { blocks with } \mathrm{N}_{2} \text { flow; freezing moni- } \\
\text { tored via camera }\end{array}$ & -25 & $50 \mu \mathrm{L}$ & 192 & $\begin{array}{l}\text { Hill et al. (2014), } \\
\text { Hiranuma et al. (2015a), } \\
\text { Barry et al. (2021) }\end{array}$ \\
\hline $\begin{array}{l}\text { Bielefeld Ice Nucleation AR- } \\
\text { raY (BINARY) }\end{array}$ & $\begin{array}{l}\text { Droplets pipetted onto a glass slide with } \\
\text { separated compartments atop a Peltier } \\
\text { cold stage, all enclosed in a, } \mathrm{N}_{2} \text {-purged } \\
\text { chamber; freezing monitored via cam- } \\
\text { era }\end{array}$ & n.f. & $0.5-5 \mu \mathrm{L}$ & 36 & Budke and Koop (2015) \\
\hline
\end{tabular}


Table 1. Continued.

\begin{tabular}{|c|c|c|c|c|c|}
\hline Instrument name & Brief description & $\begin{array}{l}\text { Water background } \\
\text { using reported } \\
\text { protocol }\left({ }^{\circ} \mathrm{C}\right)\end{array}$ & Drop size & Drops/expt. & References \\
\hline $\begin{array}{l}\text { Water-Activity-Controlled } \\
\text { Immersion Freezing Experi- } \\
\text { ment (WACIFE) }\end{array}$ & $\begin{array}{l}\text { Droplets pipetted onto a glass plate in } \\
\text { a humidity-controlled aerosol condition- } \\
\text { ing cell, then sealed from ambient air and } \\
\text { cooled on a cold stage; freezing monitored } \\
\text { via microscope }\end{array}$ & -37 & $\begin{array}{l}60-129 \mu \mathrm{m} \\
\text { diam. }\end{array}$ & $30-50$ & Wilson et al. (2015) \\
\hline $\begin{array}{l}\text { National Institute of Polar Re- } \\
\text { search Cryogenic Refrigera- } \\
\text { tor Applied to Freezing Test } \\
\text { (NIPR-CRAFT) }\end{array}$ & $\begin{array}{l}\text { Drops pipetted onto a Vaseline-coated alu- } \\
\text { minum plate cooled on a cryogenic refrig- } \\
\text { erator stage; freezing monitored via cam- } \\
\text { era }\end{array}$ & -33 & $5 \mu \mathrm{L}$ & 49 & Tobo (2016) \\
\hline $\begin{array}{l}\text { Karlsruhe Institute of Tech- } \\
\text { nology Cold Stage (KIT-CS) }\end{array}$ & $\begin{array}{l}\text { Droplets printed on a silicon substrate by } \\
\text { piezo-driven drop-on-demand generator, } \\
\text { and drops then covered in silicone oil and } \\
\text { placed on cold stage; freezing monitored } \\
\text { via CCD camera }\end{array}$ & -36 & $215 \pm 70 \mathrm{pL}$ & $\geq 1500$ & Peckhaus et al. (2016) \\
\hline $\begin{array}{l}\text { Microplate partially sub- } \\
\text { mersed in cooling liquid }\end{array}$ & $\begin{array}{l}\text { Droplets contained in 96-well microplates } \\
\text { partially submersed in a cooling water- } \\
\text { alcohol bath; freezing monitored via in- } \\
\text { frared camera }\end{array}$ & -17.3 & $150 \mu \mathrm{L}$ & $96-768$ & Zaragotas et al. (2016) \\
\hline $\begin{array}{l}\text { Carnegie Mellon University } \\
\text { Cold Stage (CMU-CS) }\end{array}$ & $\begin{array}{l}\text { Droplets of water in oil on a substrate in } \\
\text { aluminum chamber cooled with a thermo- } \\
\text { electric element; freezing monitored via } \\
\text { microscope }\end{array}$ & -27 to -28 & 1 or $0.1 \mu \mathrm{L}$ & $30-40$ & $\begin{array}{l}\text { Polen et al. (2016), } \\
\text { Polen et al. (2018) }\end{array}$ \\
\hline $\begin{array}{l}\text { Microfluidic device and cold } \\
\text { stage }\end{array}$ & $\begin{array}{l}\text { Microfluidically generated drops in oil on } \\
\text { a glass slide on a cryostage; freezing mon- } \\
\text { itored via microscope camera }\end{array}$ & -37 & $35 \mu \mathrm{m}$ diam. & 200 & Weng et al. (2016) \\
\hline $\begin{array}{l}\text { Automated Ice Spectrometer } \\
\text { (AIS) }\end{array}$ & $\begin{array}{l}\text { Drops in two 96-well PCR trays fitted into } \\
\text { aluminum blocks fixed in a liquid cooling } \\
\text { bath, all enclosed in an acrylic box; freez- } \\
\text { ing monitored via camera }\end{array}$ & -25 to -27 & $50 \mu \mathrm{L}$ & 192 & Beall et al. (2017) \\
\hline $\begin{array}{l}\text { National Oceanic and Atmo- } \\
\text { spheric Administration Drop } \\
\text { Freezing Cold Plate (NOAA- } \\
\text { DFCP) }\end{array}$ & $\begin{array}{l}\text { Drops pipetted onto Vaseline-coated cop- } \\
\text { per disk placed on a thermoelectric cold } \\
\text { plate and covered in a plastic dome; freez- } \\
\text { ing monitored optically }\end{array}$ & -30 & $2.5 \mu \mathrm{L}$ & 100 & Creamean et al. (2018) \\
\hline $\begin{array}{l}\text { Peking University Ice Nucle- } \\
\text { ation Array (PKU-INA) }\end{array}$ & $\begin{array}{l}\text { Drops pipetted into compartments on a } \\
\text { glass slide atop a cold stage in a } \mathrm{N}_{2-} \\
\text { purged box; freezing monitored via } \mathrm{CCD} \\
\text { camera }\end{array}$ & -26 & $1 \mu \mathrm{L}$ & 90 & Chen et al. (2018a) \\
\hline $\begin{array}{l}\text { WeIzmann Supercooled } \\
\text { Droplets Observation on } \\
\text { Microarray (WISDOM) }\end{array}$ & $\begin{array}{l}\text { Microfluidically produced droplet array } \\
\text { on a PDMS surface placed on a cryostage } \\
\text { purged with } \mathrm{N}_{2} \text {; freezing monitored via } \\
\text { microscope camera }\end{array}$ & -36 & $\begin{array}{l}40 \text { or } 100 \mu \mathrm{m} \\
\text { diam. }\end{array}$ & $\begin{array}{l}550(40 \mu \mathrm{m}) \text { or } \\
120(100 \mu \mathrm{m})\end{array}$ & Reicher et al. (2018) \\
\hline $\begin{array}{l}\text { Twin-plate Ice Nucleation As- } \\
\text { say (TINA) }\end{array}$ & $\begin{array}{l}\text { Droplets contained in four multiwell } \\
\text { plates }(2 \times 96 \text { and } 2 \times 384) \text { placed on two } \\
\text { custom aluminum cooling blocks; freez- } \\
\text { ing monitored via infrared camera }\end{array}$ & $\begin{array}{l}-25 \\
(96-\text { well) } \\
-28 \\
\text { (384-well) }\end{array}$ & $3 \mu \mathrm{L}$ & 960 & Kunert et al. (2018) \\
\hline Freezing on a chip & $\begin{array}{l}\text { Drops loaded on a silicon plate with } \\
\text { etched cavities and set on thermoelec- } \\
\text { tric cooler in an } \mathrm{N}_{2} \text {-flushed cell; freezing } \\
\text { monitored via camera }\end{array}$ & -37.5 & $4-300 \mathrm{pL}$ & 25 & Häusler et al. (2018) \\
\hline $\begin{array}{l}\text { InfraRed Nucleation by Im- } \\
\text { mersed Particles Instrument } \\
\text { (IR-NIPI) }\end{array}$ & $\begin{array}{l}\text { Drops pipetted into } 96 \text {-well plate on a } \\
\text { cold stage enclosed in a chamber; freez- } \\
\text { ing monitored via infrared camera }\end{array}$ & -22 & $50 \mu \mathrm{L}$ & 96 & Harrison et al. (2018) \\
\hline
\end{tabular}


Table 1. Continued.

\begin{tabular}{|c|c|c|c|c|c|}
\hline Instrument name & Brief description & $\begin{array}{l}\text { Water background } \\
\text { using reported } \\
\text { protocol }\left({ }^{\circ} \mathrm{C}\right)\end{array}$ & Drop size & Drops/expt. & References \\
\hline $\begin{array}{l}\text { Ice Nucleation Droplet Array } \\
\text { (INDA) }\end{array}$ & $\begin{array}{l}\text { Samples placed in wells of a 96-well PCR } \\
\text { tray cooled in a cooling bath; freezing } \\
\text { monitored via CCD camera }\end{array}$ & -25 & $50 \mu \mathrm{L}$ & 96 & Chen et al. (2018b) \\
\hline $\begin{array}{l}\text { Leipzig Ice Nucleation Array } \\
\text { (LINA) }\end{array}$ & $\begin{array}{l}\text { Droplets pipetted into compartments on a } \\
\text { glass slide and cooled on a Peltier ele- } \\
\text { ment; freezing monitored via CCD cam- } \\
\text { era }\end{array}$ & -30 & $1 \mu \mathrm{L}$ & 90 & Chen et al. (2018b) \\
\hline $\begin{array}{l}\text { Microfluidic droplet freezing } \\
\text { assay }\end{array}$ & $\begin{array}{l}\text { Microfluidically produced droplets in oil } \\
\text { collected in microwells on glass slides } \\
\text { placed on a Peltier cold stage in an air- } \\
\text { tight chamber; freezing monitored via mi- } \\
\text { croscope camera }\end{array}$ & -35 & $\begin{array}{l}83-99 \mu \mathrm{m} \\
\text { diam. }\end{array}$ & $250-500$ & Tarn et al. (2018) \\
\hline $\begin{array}{l}\text { Drop freeze assay experiment } \\
\text { directly on exposed filters }\end{array}$ & $\begin{array}{l}\text { Droplets pipetted onto filters placed on a } \\
\text { glass slide and cold stage in an } \mathrm{N}_{2} \text {-purged } \\
\text { chamber; freezing monitored via camera }\end{array}$ & -30 & $1 \mu \mathrm{L}$ & $\leq 130$ & Price et al. (2018) \\
\hline $\begin{array}{l}\text { West Texas Cryogenic Re- } \\
\text { frigerator Applied to Freezing } \\
\text { Test (WT-CRAFT) }\end{array}$ & $\begin{array}{l}\text { Drops pipetted onto Vaseline-coated alu- } \\
\text { minum plate and cooled on a cryogenic } \\
\text { refrigerator stage; freezing monitored via } \\
\text { camera }\end{array}$ & -26 & $3 \mu \mathrm{L}$ & 49 & Hiranuma et al. (2019) \\
\hline $\begin{array}{l}\text { DRoplet Ice Nuclei Counter } \\
\text { Zurich (DRINCZ) }\end{array}$ & $\begin{array}{l}\text { Droplets pipetted into } 96 \text {-well PCR tray } \\
\text { submersed in ethanol cooling bath; freez- } \\
\text { ing monitored via camera }\end{array}$ & -22.5 & $50 \mu \mathrm{L}$ & 96 & David et al. (2019) \\
\hline $\begin{array}{l}\text { Cold stage to detect the most } \\
\text { active INP in single crystals }\end{array}$ & $\begin{array}{l}\text { Ice crystals placed with ultrapure water on } \\
\text { a copper cold plate, melted, and refrozen; } \\
\text { freezing monitored via manual inspection }\end{array}$ & -25 & $3 \mu \mathrm{L}$ & 4 & Mignani et al. (2019) \\
\hline $\begin{array}{l}\text { "Store and create" microflu- } \\
\text { idic device }\end{array}$ & $\begin{array}{l}\text { Microfluidically generated droplets in oil } \\
\text { in microwells of a PDMS chip placed on a } \\
\text { cold plate sealed with an acrylic lid; freez- } \\
\text { ing monitored via microscope camera }\end{array}$ & -34 & $6 \mathrm{~nL}$ & $\leq 720$ & Brubaker et al. (2020) \\
\hline $\begin{array}{l}\text { Pyroelectric thermal sensor } \\
\text { for ice nucleation }\end{array}$ & $\begin{array}{l}\text { Drops pipetted onto Vaseline-coated py- } \\
\text { roelectric polymer atop a cooling block; } \\
\text { freezing monitored via pyroelectric ther- } \\
\text { mal sensor }\end{array}$ & -27 & $1 \mu \mathrm{L}$ & 30 & Cook et al. (2020) \\
\hline $\begin{array}{l}\text { University of Toronto Drop } \\
\text { Freezing Technique (UT- } \\
\text { DFT) }\end{array}$ & $\begin{array}{l}\text { Drops pipetted into multiwell PCR trays } \\
\text { cooled in an ethylene glycol water bath; } \\
\text { freezing monitored via camera }\end{array}$ & -23 & $50 \mu \mathrm{L}$ & 48 & Gute and Abbatt (2020) \\
\hline $\begin{array}{l}\text { Ice Nucleation SpEctrometer } \\
\text { of the Karlsruhe Institute of } \\
\text { Technology (INSEKT) }\end{array}$ & $\begin{array}{l}\text { Drops pipetted into two 96-well PCR trays } \\
\text { cooled in custom cooling blocks; freezing } \\
\text { monitored via camera }\end{array}$ & -20 & $50 \mu \mathrm{L}$ & 192 & $\begin{array}{l}\text { Steinke et al. (2020) } \\
\text { Schiebel (2017) }\end{array}$ \\
\hline $\begin{array}{l}\text { Lab-On-a-Chip Nucleation by } \\
\text { Immersed Particle Instrument } \\
\text { (LOC-NIPI) }\end{array}$ & $\begin{array}{l}\text { Water-in-oil droplets mirofluidically gen- } \\
\text { erated in continuous flow and passed over } \\
\text { a series of Peltier cold plates in an } \mathrm{N}_{2} \text { - } \\
\text { purged container; freezing monitored via } \\
\text { microscope camera }\end{array}$ & -36 & $\begin{array}{l}80-100 \mu \mathrm{m} \\
\text { diam. }\end{array}$ & $>1000$ & Tarn et al. (2020) \\
\hline $\begin{array}{l}\text { Freezing Ice Nuclei Counter } \\
\text { (FINC) }\end{array}$ & $\begin{array}{l}\text { Drops pipetted into three 96-well Piko } \\
\text { PCR trays submersed in ethanol cooling } \\
\text { bath; freezing monitored via camera }\end{array}$ & -25 & $5-60 \mu \mathrm{L}$ & 288 & this work \\
\hline
\end{tabular}


bath (LAUDA Proline RP 845, Lauda-Königshofen) (Fig. 1a) in which a commercially available chip-on-board LED array (50W COB Panel Light, Cooleeon Lighting Tech) is submerged $20 \mathrm{~cm}$ deep (Fig. 1b-1). A thin polytetrafluoroethylene sheet (Fig. 1b-2) acts as a diffuser mounted at a distance of $2 \mathrm{~cm}$ above the light source. A camera (IMX179 CMOS 8MP, ELP Free Driver) (Fig. 1b-3) mounted above the bath images clear Piko ${ }^{\text {TM }}$ PCR trays made of polypropylene (SPL0960, Thermo Fisher Scientific) (Fig. 1b-4) resting on the frame at the bath's surface. A level sensor (LLE102000, Honeywell) (Fig. 1b-5) measures the height of the ethanol in the bath, and a peristaltic pump (KAS-S10SE, Kamoer) (Fig. 1b-6) controlled by a micro-controller (Leonardo, Arduino ${ }^{\circledR}$ ) (Fig. 1b-7) and powered by a stepper motor driver (TB6612, Adafruit) (Fig. 1b-7) moves ethanol between the LAUDA chiller bath and the ethanol reservoir (Fig. 1b-8) (Fig. 1c). A transparent $6 \mathrm{~mm}$ thick polymethyl methacrylate (Plexiglas) plate (Fig. 1b-9) covers the Piko PCR trays to avoid contamination of the wells, minimize evaporative loss of ethanol, and limit condensation of water vapor into the ethanol (see Sect. 4.4.2). The components are mounted to a removable aluminum frame with stainless-steel rods, which is recommended to avoid corrosion over time (Fig. 1a, b). Consumer-grade hardware was used as building components when possible to reduce the overall instrument cost while ensuring measurement accuracy and reproducibility. The bulk of the building costs are constrained to the ethanol cooling bath. The per-measurement cost is dominated by laboratory consumables, such as the Piko PCR trays.

\subsubsection{PCR trays}

The use of Piko PCR trays in FINC is an updated feature of existing DFTs (Table 1). Specifically, standard PCR trays contain 96 wells of $200 \mu \mathrm{L}$ volume with dimensions of $127.76 \mathrm{~mm}$ by $85.34 \mathrm{~mm}$, whereas the Piko PCR trays used in FINC contain 96 wells of $65 \mu \mathrm{L}$ volume with dimensions of $80.55 \mathrm{~mm}$ by $26.75 \mathrm{~mm}$. The smaller dimensions allow for the use of up to four 96-well Piko PCR trays instead of one standard PCR tray, resulting in improved freezing temperature statistics per experiment. The trays are heated in an oven at $120^{\circ} \mathrm{C}$ for at least $1 \mathrm{~h}$ before use; this procedure improves reproducibility of background water experiments (Fig. S3). In FINC, we use three Piko PCR trays to optimize the ethanol circulation and temperature spread across the 288 sample wells (see Sect. 3.2).

\subsubsection{Bath leveler}

An automated bath leveler system was built to account for the temperature dependence of the density of ethanol in FINC's cooling bath. For example, ethanol's density at 0 and at $-25^{\circ} \mathrm{C}$ is 806.7 and $826.3 \mathrm{~g} \mathrm{~L}^{-1}$, respectively. This increase in density at lower temperatures consequently translates to a decrease in volume in the cooling bath and corresponds to a $4.9 \mathrm{~mm}$ decrease in height, equivalent to approximately $300 \mathrm{~mL}$ of ethanol, between 0 and $-25^{\circ} \mathrm{C}$. To achieve reproducible measurements, the ethanol level must submerge the well throughout the experiment to avoid the formation of vertical temperature gradients within the well (David et al., 2019). In FINC, a constant ethanol level is maintained by adding and removing ethanol to the cooling bath via a peristaltic pump (Fig. 1c), thereby automating this process. The binary level sensor outputs either a submerged or emerged status signal to the micro-controller, which then turns the pump in the corresponding direction: either moving ethanol from the reservoir to the cooling bath during the experiment or removing ethanol from the bath back to the reservoir during warm-up at the end of the experiment (Fig. 1c). The leveler does not need to be adjusted depending on the well volume used, as capillary action between the wells of the Piko PCR tray ensures that all wells are submerged in ethanol as long as the ethanol reaches the bottom of the wells. In all, freezing measurements in FINC occur without manual intervention between measurements except for removing and placing new Piko PCR trays.

\subsection{Cooling rate}

The cooling bath temperature is controlled by a MATLAB ${ }^{\circledR}$ script ramping down at $-1{ }^{\circ} \mathrm{C} \mathrm{min}{ }^{-1}$ while the script records an image every $0.2{ }^{\circ} \mathrm{C}$. We prefer to record images as a function of temperature rather than as a function of time to ensure that all measurements have identical increments and can be easily averaged without interpolation. The cooling rate has been previously reported to have a negligible effect on immersion freezing temperatures (Wright et al., 2013), although much faster cooling can lead to temperature assignment uncertainties (Mason et al., 2015). Thus, we chose a cooling rate matching atmospheric updraft velocities and within the capacity of the LAUDA bath's cooling mechanism.

\subsection{Freezing detection}

The freezing of the solutions inside the wells of the Piko PCR trays is detected by a change in light intensity passing through the wells. Light passes through liquid water but is scattered by ice, resulting in dark pixels in the image (Fig. 1d). Once the images are recorded over the course of one experiment, a circular Hough transform algorithm, described in David et al. (2019), is implemented to locate the wells on the images (Fig. S1). In the case of failure of the automatic well detection, we also developed a filtered algorithm output to identify the well positions, as well as a manual well alignment grid, by selecting two wells in opposing corners. After determining the well positions, the average pixel intensity is calculated for each well per image. This data analysis generates an intensity profile as a function of temper- 


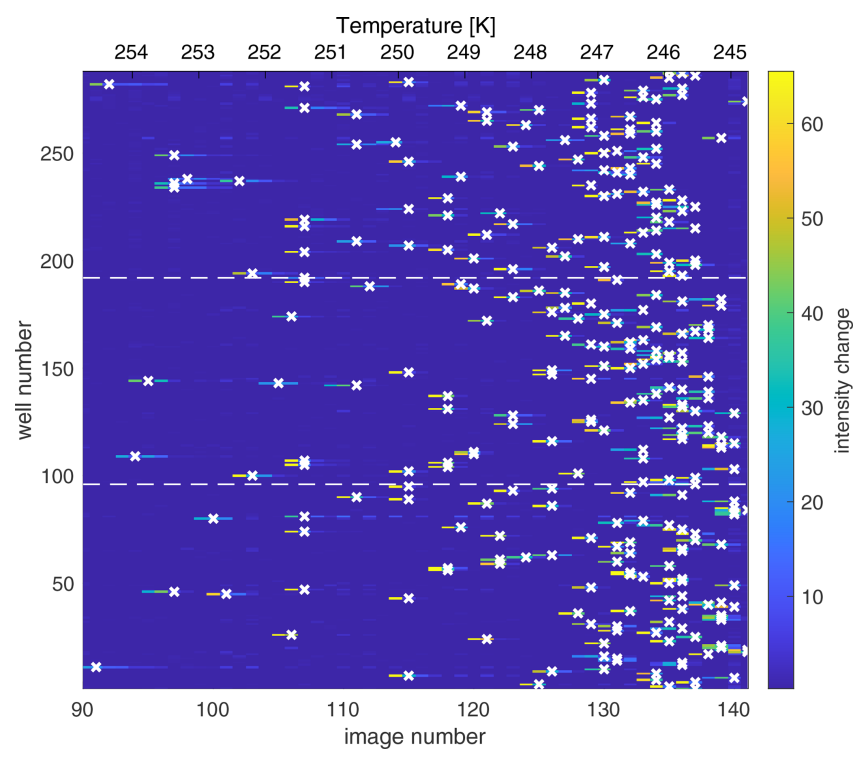

Figure 2. Map of the change in light intensity for each of the 288 wells ( $y$ axis) as a function of the image number ( $x$ axis), recorded every $0.2^{\circ} \mathrm{C}$ and corresponding to temperature decreasing and experimental time progressing. (The first 90 images corresponding to an interval of $18^{\circ} \mathrm{C}$ are excluded here for simplicity). The color scale represents the first derivative of the light intensity, with bright colors indicating a sudden drop in light intensity associated with freezing of the well. The algorithm assigns the freezing temperature of the well to the greatest change in light intensity and is marked by a white " $x$ ". The dashed horizontal lines indicate the tray boundaries between the three Piko PCR trays. The freezing experiment depicts the results of a background water measurement.

ature. Then, the greatest change in intensity is attributed to the freezing temperature and can be visualized as a temporal map (Fig. 2). For example, multiple changes in light intensity for one well over the course of an experiment or neighboring wells freezing at the same temperature can flag an error (for example, an object in front of the camera), requiring manual deletion of some images or a rerun of the measurement. A color map of the freezing temperature is also generated to visually inspect any well location bias (Fig. S2) (David et al., 2019). These data verification steps increase confidence in the measurement.

The data output of FINC is a vector containing the freezing temperature of each well. The vector is sorted by well column from top to bottom and left to right (see Fig. S1). In addition, a frozen fraction graph can be plotted by sorting the freezing temperature vector and plotting it versus a linearly spaced vector with values ascending from 0 to 1 in 288 steps (example in Fig. S3). Based on the recommendation by Polen et al. (2018), the data are not trimmed, and all 288 freezing temperature data points are plotted. These data manipulations retain all information available from the experiment: freezing temperature and well location in one vector.

\subsection{Sample preparation and data analysis}

Sample solutions were prepared within a laminar flow hood (Labculture Class II BioSafety Cabinet, ESCO) to prevent contamination from lab air. All glassware was pre-rinsed three times with deionized water and acetone, and it was subsequently dried in an oven at $120^{\circ} \mathrm{C}$ for at least $1 \mathrm{~h}$. Sample solutions were then prepared using molecular-biologyfree reagent water (W4502, Sigma Aldrich, hereafter referred to as background water). The solutions were then pipetted from sterile plastic reservoirs (10141-922, VWR) with an electronic multi-pipettor (4671040BT, Thermo Fisher Scientific, USA) into pre-cleaned Piko PCR trays (see Sect. 2.1.2). We recommend pipetting the solution volume in one dispensing volume to minimize the formation of bubbles (see Sect. 4.4.4). In addition, Barry et al. (2021) recently suggested working with clean-room vinyl or polyethylene gloves and aluminum-foil-coated surfaces.

When transporting the Piko PCR trays from the laminar flow hood to FINC, we placed cover films (Z369667, Sigma Aldrich) over the trays to avoid contamination from ambient air. We removed the cover film before placing the trays inside the ethanol bath in order to avoid problems with ethanol penetrating between the cover film and the Piko PCR tray by capillary effects. Furthermore, the Plexiglass hinged cover over the trays prevents contamination from the air depositing into the wells.

Note that our sample preparation procedure does not include dilution series; we made the solutions with the required concentration from weighed solid. We have previously proposed that lignin may be aggregating in solution, leading to concentration-dependant ice nucleation behavior of INMs (Bogler and Borduas-Dedekind, 2020). Based on this hypothesis, we also do not conduct any data merging procedure for different concentrations of INMs or drop volumes (for example in Figs. S6 and S7). Furthermore, we do not subtract background water values and prefer to show raw data in box plot formats (as in Fig. 7; see also Brennan et al., 2020).

\section{$3 \quad$ FINC's uncertainties}

\subsection{Temperature uncertainty}

A temperature calibration is necessary to correct for the difference between the recorded temperature of the LAUDA bath and the temperature within each well. This calibration was done using a multichannel thermocouple data logger (HH-4208SD, Thermosense, UK), whereby each K-type thermocouple was placed inside a well filled with ethanol, with nine thermocouples evenly spaced across the three trays. With the probes inside the wells, the bath temperature was ramped down to $-30^{\circ} \mathrm{C}$ at a rate of $-1{ }^{\circ} \mathrm{C} \mathrm{min}-1$. The temperature of each thermocouple was recorded every $10 \mathrm{~s}$ ( $\left.T_{\text {well }}\right)$ and was plotted against the bath temperature recorded 
by the LAUDA system $\left(T_{\text {bath }}\right)$, as shown for one calibration experiment in Fig. S4. We then obtained the following calibration equation (Eq. 1), wherein the slope and intercept are averaged values across three independent calibration experiments.

$T_{\text {well,avg }}=0.95 \times T_{\text {bath }}+0.75$

Multiple temperature calibrations conducted several months apart and by multiple users led to identical slopes, confirming reproducible temperature gradients and constant ethanol circulation inside the bath. The mean of the standard deviations of the nine evenly spaced thermocouples across three Piko PCR trays was $0.5^{\circ} \mathrm{C}$ for temperatures down to $-25^{\circ} \mathrm{C}$ (Table S1). We therefore report the temperature uncertainty for each well to be $\pm 0.5^{\circ} \mathrm{C}$.

\subsection{Temperature spread across wells}

Furthermore, we tested different numbers of Piko PCR trays and different bath pump speeds to reduce the temperature bias across the three trays within an experiment (Sect. S3, Table S1). Tests with four trays led to the identification of a vortex in the upper left corner of the ethanol bath, yielding higher temperature biases across the trays (Table S1). Overall, we determined that using three trays placed to the right to avoid the vortex, as well as pump speed setting 8 , resulted in the smallest temperature biases of $\pm 0.46^{\circ} \mathrm{C}$ between -10 and $-15^{\circ} \mathrm{C}$ and of $\pm 0.55^{\circ} \mathrm{C}$ between -20 and $-25^{\circ} \mathrm{C}$ (Table S1, last row). Since the average of these values is precisely $0.5^{\circ} \mathrm{C}$, we consider this value to be equal to the temperature uncertainty described in Sect. 3.1.

\subsection{FINC's limit of detection}

It is necessary to accurately characterize the background of the instrument to determine the lowest trustworthy freezing temperature of a sample. FINC's limit of detection (LOD) for the freezing control experiments (Sect. 4) was calculated as the mean of 10 replicates of background water experiments using $5 \mu \mathrm{L}$ droplets (Fig. S5). We calculated the mean temperature and 1 standard deviation (a spread of $1 \sigma$ ) for each of the 288 values, resulting in an LOD $T_{50}$ of $-25.4 \pm 0.2^{\circ} \mathrm{C}$. We note that a value of $\pm 3 \sigma$ can also be used and would lead to a similar background $T_{50}$ of $-25.4 \pm 0.4^{\circ} \mathrm{C}$ (Fig. S5). Furthermore, we show the LOD as a box plot of the mean frozen fraction (Fig. S5). The LOD depends on the experiment type, but as long as the appropriate background characterizations are measured, e.g., artificial salt water, background water, and water through a laboratory setup, the instrument can be used to measure freezing temperatures of 288 wells at a time (see Sect. 4.5 for a further discussion). Finally, we add that no background corrections are made in our data analysis.

\section{Freezing control experiments}

To test the capabilities of FINC and to characterize its sources of uncertainties, we conducted several freezing control experiments. We considered (1) the nonhomogeneous freezing of the background water (Sects. 4.1 and 4.2), (2) the roles of tray material and of droplet shape (Sect. 4.3), (3) eight different sources of contamination (Sect. 4.4), (4) the choice of well volume (Sect. 4.5), and (5) the freezing-point depression of a dissolved organic matter solution with different salt concentrations (Sect. 4.6).

\subsection{Nonhomogeneous freezing in FINC}

The use of Piko PCR trays allows for a range of sample volumes of 5-60 $\mu \mathrm{L}$ to be measured in FINC. Theoretically, freezing rates of water droplets are dependent on the volume of the droplet; smaller droplets freeze at lower temperatures (O and Wood, 2016; Koop and Murray, 2016). Classical nucleation theory approximates interfacial tension between ice and water, the activation energy of the phase transfer, and the size of clusters and embryos (Ickes et al., 2015). In the atmosphere, $50 \%$ of a droplet population of $5 \mu \mathrm{L}$ volume is predicted to freeze spontaneously $(<1 \mathrm{~s})$ and thus homogeneously at $-31.81^{\circ} \mathrm{C}$, whereas $60 \mu \mathrm{L}$ volume is predicted to freeze at $-31.41^{\circ} \mathrm{C}$ (equations from Wang, 2013). However, these temperatures were never reached during FINC experiments with background water. Over the range of possible sample volumes in FINC $(5-60 \mu \mathrm{L})$, the mean $T_{50}$ value of background water was $-24.5 \pm 0.8^{\circ} \mathrm{C}$. DFTs tabulated in Table 1, which use drops in the microliter range, also show this nonhomogeneous freezing behavior. As argued in the following sections, the difference in temperatures between atmospheric homogeneous freezing and background water freezing in FINC is likely due to a combination of tray material (Sect. 4.3.1), nonspherical drop shapes within the wells (Sect. 4.3.2), and different sources of contamination (Sect. 4.4).

\subsection{Volume dependence on nonhomogeneous freezing}

We further attempted to quantify these uncertainties by comparing the $T_{50}$ values of background water over a range of background water volumes. The mean $T_{50}$ background water values in FINC were $-25.4 \pm 0.1^{\circ} \mathrm{C},-24.7 \pm 0.1^{\circ} \mathrm{C}$, $-23.4 \pm 0.6^{\circ} \mathrm{C},-24.5^{\circ} \mathrm{C},-24.4 \pm 0.2^{\circ} \mathrm{C},-25.2^{\circ} \mathrm{C}$, and $-25.3 \pm 0.1^{\circ} \mathrm{C}$ for $5,10,20,3040,50$, and $60 \mu \mathrm{L}$, respectively, across one to five replicates (Table S2; Fig. S6). Furthermore, if we collect all the freezing temperatures from different volumes described in Sect. 4.1 and convert the data into INPs per volume, we observe a large spread in the freezing behavior of the water (Fig. S7). Through both these data analyses, we observe that experiments with $20 \mu \mathrm{L}$ of background water freezes warmer and with a larger spread than all other volumes. In Sects. 4.3 and 4.4, we investigate and dis- 
cuss the potential sources of contamination involved in creating a volume-dependent nonhomogeneous freezing temperature, and we attempt to reason the unpredictable behavior of the $20 \mu \mathrm{L}$ freezing experiments.

\subsection{Potential uncontrollable factors affecting nonhomogeneous freezing}

\subsubsection{Effect of tray material}

As described in detail in Li et al. (2012) and Polen et al. (2018), the material interacting with the supercooled water droplets impacts their freezing. Indeed, the Piko PCR trays used in FINC are made of polypropylene and are therefore a hydrophobic surface. Interestingly, hydrophobic surfaces have previously been observed to freeze at a warmer temperature than hydrophilic surfaces ( $\mathrm{Li}$ et al., 2012). It is likely that the material of the tray is contributing to warmer temperatures than expected for homogeneous freezing, but it is difficult to quantify the extent or percentage of this contribution to the overall nonhomogeneous freezing behavior. Imperfections on the surface of each well could also induce nonhomogeneous freezing behavior (Diao et al., 2011), and the use of a larger number of wells could help provide reliable statistics.

\subsubsection{Effect of drop shape}

Due to the narrow width of the Piko PCR tray wells, the water in FINC's wells is subjected to capillary forces. Indeed, a concave meniscus is evident when examining the solution in the Piko PCR trays, thereby exerting negative pressure on the solution. It has been previously shown that the homogeneous nucleation rate of water can be significantly increased when water is subjected to negative pressure (Marcolli, 2017, 2020). However, the negative pressure associated with the radius of the meniscus in the Piko wells is on the order of 1-3 mm (see Table S3 and Fig. S10) and is likely negligible in terms of participating in nonhomogeneous freezing in FINC (Marcolli, 2017, 2020). Nevertheless, classical nucleation theory assumes spherical supercooled water droplets, whereas DFTs using a cold stage or PCR trays rather investigate the freezing behavior of halfspheres or cone-shaped supercooled droplets.

\subsection{Potential controllable sources of contamination}

\subsubsection{Effect of background water contamination}

Background water is a contentious issue in the field of atmospheric ice nucleation. An excellent overview of the challenges of "cleaning up our water" is described in Polen et al. (2018). Upon their recommendation, we experimented with different types of purified water and found that the molecular-biology-free reagent water (i.e., background water) gave the most reproducible measurements, consistent with David et al. (2019). Filtration of the background water through a $0.02 \mu \mathrm{m}$ filter led to no difference in freezing behavior for the background water, except for our lab's Milli-Q water, which is known to contain higher levels of organic carbon (Fig. S8). We therefore chose to work with commercial molecular-biology-free reagent water from Sigma Aldrich without further purification.

\subsubsection{Effect of condensing water vapor}

We considered the possibility of water vapor condensing into the wells from the air between the Plexiglass and the trays during a measurement (Fig. S9). We calculated a maximum amount of condensable water vapor or, in other words, a worst-case scenario in which if the volume of water vapor corresponding to $90 \% \mathrm{RH}$ at $0{ }^{\circ} \mathrm{C}$ between the Plexiglass and the trays were to condense into liquid water inside a well, we would arrive at a value of $2 \mathrm{~nL}$ (Sect. S7). This volume is small and unlikely to be able to condense into one well, freeze on a colder wall, and trigger nucleation within the well. We therefore conclude that this condensation process has a negligible effect on the well volume and thus on freezing temperatures.

\subsubsection{Effect of the surface area of the tray}

We considered whether a difference in the surface area to volume ratio could explain the different $T_{50}$ values observed for different volumes depicted in Fig. S6 (see Sect. S8 for the calculations of surface areas of the wells). In particular, we hypothesized that the warmer freezing of the $20 \mu \mathrm{L}$ could be due to the cone-like shape of the well (see the shape diagram in Fig. S10). However, the surface area to volume ratios of the different volumes shown in Fig. S11 could not explain the variability or higher freezing temperatures observed, particularly with $20 \mu \mathrm{L}$. Note that the water vapor condensation is inconsequential to changing the surface area to volume ratio (Sect. 4.4.2). Our running hypothesis for the peculiar higher freezing of the $20 \mu \mathrm{L}$ experiments is the presence of microscopic bubbles generated at the intersection of the two truncated cones when using this volume (Sect. 4.4.4).

\subsubsection{Effect of air bubbles in the wells}

Air bubbles in the solutions within a well can be generated during the pipetting process, particularly if the solution mixture has surfactant-like properties (see the example image in Fig. S12). Bubbles are defined here as visible pockets of air in the well. This problem is likely the result of a combination of trapped air in the narrow wells during dispensing. Wells containing bubbles in FINC (Fig. S12) froze at warmer temperatures (Fig. S13). When the bubbles collapsed within the well, they may have created a spike in negative pressure, inducing freezing at warmer temperatures than in the absence of bubbles (Marcolli, 2017). Therefore, bubbles should be avoided by careful introduction of the solution into the well. Since bubbles associated with pipetting can be seen in the 
images, we can confirm the absence of bubbles in all images used for the data plotted in Fig. S6. As no visible bubbles were present, then this potential effect is unlikely to explain the observed nonhomogeneous freezing behavior for different well volumes. Nevertheless, microscopic bubbles invisible to the human eye and to the camera could be affecting the nonhomogeneous freezing, including for the $20 \mu \mathrm{L}$ volumes, but to an unknown degree.

\subsubsection{Effect of contamination from the tray}

A series of experiments was conducted to test the leaching of potential ice-active material from the Piko PCR trays into the background water. To test this hypothesis, we placed $60 \mu \mathrm{L}$ of background water into one tray and then pipetted $50 \mu \mathrm{L}$ of the water out of each well and into another tray. If leaching was indeed a problem, we would have observed higher freezing temperatures in the tray containing the transferred solution. However, we found no effect of freezing from leaching over duplicate sets of experiments (Fig. S14). We conclude that material leaching from the Piko PCR trays is not a problem.

\subsubsection{Effect of lab air contamination}

As discussed by Whale et al. (2015) and Stopelli et al. (2014), the concept of an open droplet system can be prone to further contamination from the surrounding air. We have built upon the authors' recommendations by using a laminar flow hood, placing a cover film on the top of the Piko PCR tray between the flow hood and FINC, and having a Plexiglass cover on FINC to minimize deposition of airborne contaminants. Furthermore, we calculated the surface area of the solution exposed to air but observed no trend related to the nonhomogeneous freezing behavior for different well volumes (see Table S3).

\subsection{Volume of solution per well discussion and recommendation}

Based on Sects. 4.1, 4.2, 4.3, and 4.4, it remains difficult to quantify the contribution of each possible source of contamination to nonhomogeneous freezing. This difficulty appears to be a combination of uncontrollable (Sect. 4.3) and controllable factors (Sect. 4.4), and this difficulty has been previously addressed in Polen et al. (2018). Nevertheless, the pre-treatment of the trays (see Fig. S3), the use of a laminar flow hood, and the use of molecular-biology-free reagent water allowed for reproducible background water measurements. In all, the recommended well volume while working with FINC depends on the research question. One should use a larger volume to study active, but less abundant, INPs and INMs, whereas one should use a smaller volume to study less active, but more abundant, INPs and INMs. If the samples have high concentrations of salts leading to freezing-point depression, for instance, then a larger volume might be necessary to remain in the operating range of the LAUDA bath.

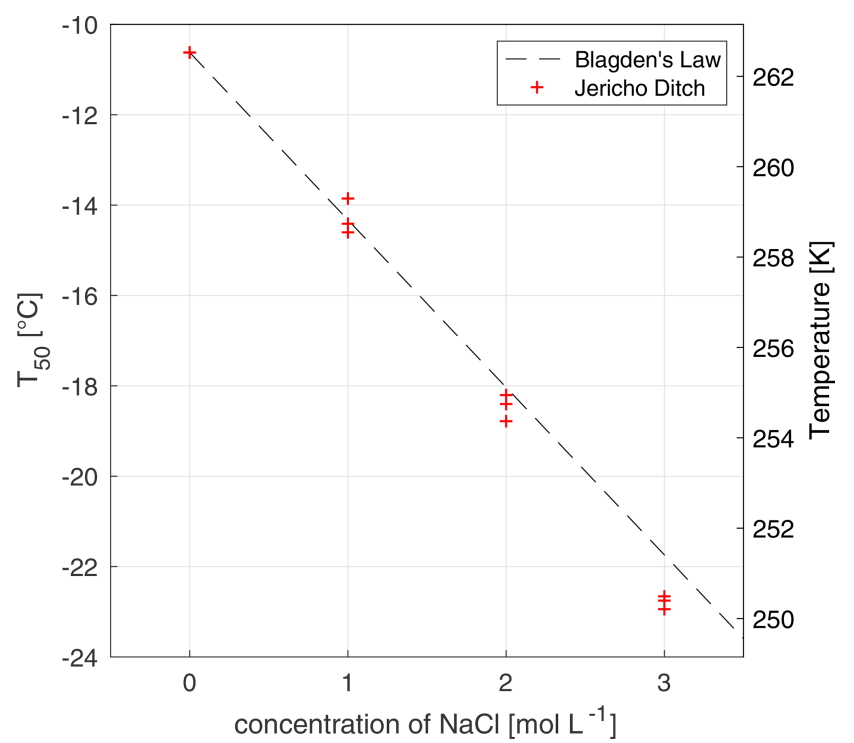

Figure 3. The freezing-point depression effect of solutions of $20 \mathrm{~m} \mathrm{C} \mathrm{L} \mathrm{L}^{-1}$ of Jericho Ditch dissolved organic matter with increasing concentrations of sodium chloride $(\mathrm{NaCl})$. The $x$ axis represents the concentration $\left(\mathrm{mol} \mathrm{L}^{-1}\right)$ of $\mathrm{NaCl}$, and the $y$ axis represents the $T_{50}$ values, where $50 \%$ of the wells were frozen. Triplicate experiments were done for concentrations of $0,1,2$, and $3 \mathrm{M}$ of $\mathrm{NaCl}$, marked with red crosses. Note that the $T_{50}$ values for the experiments at $0 \mathrm{~mol} \mathrm{~L}^{-1}$ are identical and thus overlap. Experimental data were compared to Blagden's law (grey dashed line), which describes the freezing-point depression phenomenon. All temperature measurements have an uncertainty of $\pm 0.5^{\circ} \mathrm{C}$.

\subsection{Freezing-point depression}

Inorganic salts have a freezing-point depression effect on water's freezing temperature (e.g., Koop et al., 2000b). The effect is described in general by the relationship in Eq. (2), commonly known as Blagden's law:

$\Delta T_{\mathrm{f}}=K_{\mathrm{f}} \times b_{\mathrm{b}}$,

where $\Delta T_{\mathrm{f}}$ is the freezing-point depression, $K_{\mathrm{f}}$ is the cryoscopic constant of the solvent $\left(K_{\mathrm{f} \text {,water }}=1.86 \mathrm{~K} \mathrm{~kg} \mathrm{~mol}^{-1}\right)$, and $b_{\mathrm{b}}$ is the molality of the solute (Atkins and de Paula, 2011). To further characterize FINC, we tested the ice nucleation activity of solutions of dissolved organic matter (DOM) and sodium chloride (NaCl; 31 434, Sigma Aldrich). The DOM solutions were at concentrations of $20 \mathrm{mg} \mathrm{CL}^{-1}$ (milligrams of carbon per liter) and were samples obtained from Jericho Ditch, part of the Great Dismal Swamp in Suffolk, Virginia, USA (sample collection reported in Borduas-Dedekind et al., 2019). Jericho Ditch DOM is ice-active, with a $T_{50}$ value of $-10.6 \pm 0.0^{\circ} \mathrm{C}$ (Fig. 3), and is therefore a suitable sample for freezing-point depression tests. We determined a linear freezing-point depression effect with increasing concentrations of salt, as expected by the theoretical values 

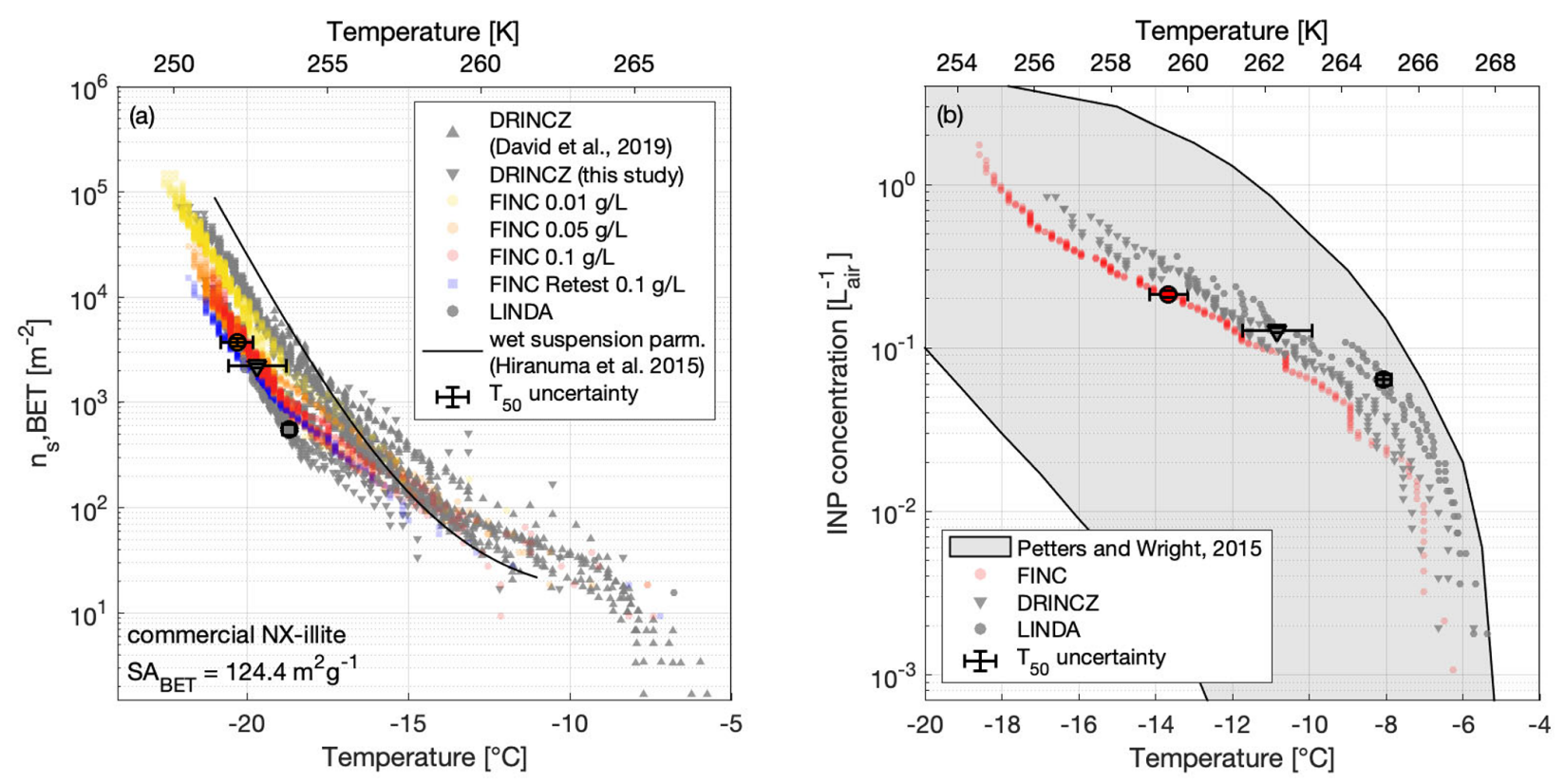

Figure 4. (a) The active surface-site density $n_{\mathrm{s}, \mathrm{BET}}$ of NX-illite suspensions measured on FINC (yellow, orange, red dots), DRINCZ (grey downward triangles), and LINDA (grey dots) during the intercomparison. The wet suspension parameterization by Hiranuma et al. (2015a) is plotted for reference. Concentrations used were $0.1,0.05$, and $0.01 \mathrm{~g} \mathrm{~L}^{-1}$ of NX-illite. The DRINCZ illite measurements as reported in David et al. (2019) are also shown for comparison (grey upwards triangles). $n_{\mathrm{s}, \mathrm{BET}}$ was calculated using a BET surface area of $124.4 \mathrm{~m}^{2} \mathrm{~g}^{-1}$ (Hiranuma et al., 2015a). Error bars in the $x$ and $y$ direction are shown on the $T_{50}$ value for one sample each from DRINCZ, LINDA, and FINC (see Supplement Sect. S11 for details). Note that the $y$-direction uncertainties do not extend beyond the marker. (b) INP concentrations $\left(\mathrm{L}_{\text {air }}^{-1}\right)$ of an ambient aerosol sample solution from Zurich, Switzerland, measured on FINC (red dots), DRINCZ (grey triangles), and LINDA (grey dots). Ambient aerosols were collected with a Coriolis $\mu$ impinger for $20 \mathrm{~min}$ at $300 \mathrm{~L} \mathrm{~min}^{-1}$. The sample was split for measurements on each of the immersion freezing instruments. One measurement run was done with FINC; two runs each were done with DRINCZ and LINDA. The grey shaded area denotes the range of INP concentrations from precipitation and cloud water samples compiled by Petters and Wright (2015). Error bars in the $x$ and $y$ direction are shown on the $T_{50}$ value for one sample each from DRINCZ, LINDA, and FINC (see Supplement Sect. S11 for details). Note that the $y$-direction uncertainties do not extend beyond the marker.

calculated according to Blagden's law (Fig. 3; Eq. 2). Our saline DOM solutions measured with FINC match Blagden's law well. However, a small deviation was observed with a $3 \mathrm{M} \mathrm{NaCl}$ solution, likely due to activity coefficients deviating from unity. This experiment further validates the instrument's capabilities to be used in a droplet freezing technique (Fig. 3).

\section{Drop freezing instrument intercomparison and validation of FINC}

To validate FINC against other similar and peer-reviewed DFTs, we conducted an intercomparison study with ETH's DRINCZ (David et al., 2019) and the University of Basel's LINDA (Stopelli et al., 2014) (Sect. 5.1). Here, we report the comparison measurements using NX-illite (Sect. 5.2) and an ambient aerosol sample (Sect. 5.3).

\subsection{Experimental details of DRINCZ and of LINDA}

DRINCZ was operated using a freshly shaken sample poured into a sterile reservoir. Then, 96 droplets of $50 \mu \mathrm{L}$ were transferred into a 96-well PCR polypropylene tray (732-2386, VWR, USA) using an eight-channel multi-pipette. The tray was sealed with a transparent foil and immediately analyzed with DRINCZ as described in David et al. (2019). LINDA was operated using a total of $5.2 \mathrm{~mL}$ per experiment, and each sample was shaken by hand and immediately pipetted under a laminar flow hood (AURA Mini, EuroClone) into 52 microtubes $(0.5 \mathrm{~mL}$ Eppendorf Safe-Lock Tubes) using a repeater pipette (Stepper TM 411, Socorex) and bioproof syringes (Ecostep TM, sterilized, single wrapped, bioproof; range $50-500 \mu \mathrm{L}$ ). Each droplet contained $100 \mu \mathrm{L}$ of the sample solution and was measured with LINDA according to Stopelli et al. (2014).

All samples for the intercomparison were prepared at ETH Zurich on 10 July 2019. On the following day, measurements with all three instruments were conducted. As LINDA was located in Basel, one batch of aliquots was transported in 
a cooler by train in the morning from the preparation location (in Zurich) to the measurement location (in Basel). For background measurements, purchased, bottled molecularbiology-free reagent water (Sigma-Aldrich, W4502-1L) was used (background measurements reported in Fig. S15), and no background corrections were made.

\subsection{NX-illite intercomparison}

NX-illite has been repeatedly used as a standard to compare ice nucleation instruments (e.g., Hiranuma et al., 2015a). Commercial NX-illite solutions of 0.01, 0.005, and $0.001 \%$ wt (or $0.1,0.05$, and $0.01 \mathrm{~g}$ of $\mathrm{NX}$-illite per $1 \mathrm{~L}$ of water, respectively) were measured by FINC, DRINCZ, and LINDA during an intercomparison experiment day on 11 July 2019 (Fig. 4a). The three instruments measured the same suspension; one suspension of each concentration was split into several sterile Falcon tubes (14-432-22, Thermo Fisher Scientific, USA). The Falcon tubes were shaken immediately prior to pipetting, and the filled PCR trays were not left to sit more than a few minutes prior to the freezing experiment. We calculated, according to Eq. (3) (Vali, 1971, 2019), the ice-active surface-site density $\left(n_{\mathrm{s}, \mathrm{BET}}\right)$, where BET stands for the Brunauer-Emmett-Teller technique, a commonly used technique to measure particle surface areas (Brunauer et al., 1938):

$n_{\mathrm{s}, \mathrm{BET}}(T)\left[\mathrm{m}^{-2}\right]=-\frac{\ln [1-\mathrm{FF}(T)]}{\mathrm{SA}_{\mathrm{BET}} \times C_{\text {illite }} \times V_{\text {well }}}$,

where $\mathrm{FF}(T)$ is the frozen fraction at each freezing temperature, $\mathrm{SA}_{\mathrm{BET}}$ is the BET-determined surface area of the NX-illite particles $\left(124.4 \mathrm{~m}^{2} \mathrm{~g}^{-1}\right.$; Hiranuma et al., 2015a), $C_{\text {illite }}$ is the mass concentration of NX-illite, and $V_{\text {well }}$ is the volume in each well $\left(V_{\text {well }}=30 \mu \mathrm{L}\right.$ for FINC, $50 \mu \mathrm{L}$ for DRINCZ, and $100 \mu \mathrm{L}$ for LINDA). The uncertainties in $n_{\mathrm{s}, \mathrm{BET}}$ include a $1 \%$ error in SABET (Broadley et al., 2012), $1 \%$ error in $C_{\text {illite }}, 1 \%$ error in $V_{\text {well,DRINCZ }}, 0.5 \%$ error in $V_{\text {well,LINDA }}, 8 \%$ error in $V_{\text {well,FINC (well volume errors are }}$ based on error in pipettes), and an error of \pm 1 in the number of frozen wells. Uncertainty calculations are detailed in Sect. S11 and plotted in Fig. 4a as vertical error bars on the $T_{50}$ values for one sample from each instrument.

We additionally compare these measurements with NXillite solutions measured on DRINCZ in 2018 (David et al., 2019) and with the parameterization from Hiranuma et al. (2015a) (Fig. 4a).

The FINC measurement spread at $-15^{\circ} \mathrm{C}$ is from 68 $209 \mathrm{~m}^{-2}$ and grows to $2600-9200 \mathrm{~m}^{-2}$ at $-20^{\circ} \mathrm{C}$. The Hiranuma et al. (2015a) parameterization fits well within the FINC measurements above $-17^{\circ} \mathrm{C}$ and deviates up to a factor of 4.8 at $-21^{\circ} \mathrm{C}$. Between FINC, DRINCZ, and LINDA, the spread was a factor of 6 at $-15^{\circ} \mathrm{C}$ and a factor of 7.5 at $-20^{\circ} \mathrm{C}$. The DRINCZ measurements from David et al. (2019) are up to 1 order of magnitude higher than those reported here (Fig. 4a). Indeed, the spread of $n_{\mathrm{s}, \mathrm{BET}}$ is a com- mon outcome of NX-illite suspensions (e.g., David et al., 2019; Harrison et al., 2018; Beall et al., 2017). We hypothesize that this spread is due to the heterogeneity of the suspensions; the NX-illite particles can settle and sediment to the bottom of the wells, reducing the available surface area to nucleate ice. Furthermore, sedimentation increases with concentration, consistent with the observation of lower $n_{\mathrm{s}, \mathrm{BET}}$ values at higher concentrations (Fig. 4a). To further test this hypothesis, we retested the $0.1 \mathrm{~g} \mathrm{~L}^{-1}$ solution on FINC 8 months later and found that the $n_{\mathrm{s}, \mathrm{BET}}$ values had decreased by approximately a factor of 5 at $-20^{\circ} \mathrm{C}$ (Fig. 4a, sample FINC retest in blue). This change in $n_{\mathrm{s}, \mathrm{BET}}$ values suggests that NX-illite suspensions are not stable over time, consistent with mineral dust experiments demonstrating ion exchange abilities in solution over time (Kumar et al., 2019). Nevertheless, the results of this intercomparison with NX-illite support the validation of FINC as a suitable instrument for quantifying ice-nucleating activity in the immersion freezing mode, as well as strengthening our proposal for a more solution-stable standard.

\subsection{Ambient aerosol intercomparison}

Next, we measured the INP concentration of an ambient aerosol sample during the intercomparison study with DRINCZ and LINDA. Ambient aerosols were collected with a Coriolis $\mu$ air sampler (Bertin Technologies, France), an instrument designed for outdoor monitoring of bio-aerosols such as pollen and spores (Gómez-Domenech et al., 2010; Carvalho et al., 2008). The sample was collected for $t_{\mathrm{aq}}=$ $20 \mathrm{~min}$ at a flow rate of $Q=300 \mathrm{~L} \mathrm{~min}^{-1}$ on 10 July 2019 on the terrace of the Institute for Atmospheric and Climate Science at ETH Zurich in Switzerland. The initial sample volume $v=15 \mathrm{~mL}$ was further diluted with a dilution factor of $\mathrm{DF}=3.7$ to obtain enough volume to split into sterile Falcon tubes and brought to FINC, DRINCZ, and LINDA for measurement the following day. The INP concentration per liter of air was calculated by Eq. (4).

$\operatorname{INP}(T)\left[\mathrm{L}_{\text {air }}^{-1}\right]=-\frac{\ln [1-\mathrm{FF}(T)]}{V_{\text {well }}} \times \frac{\mathrm{DF} \times v}{t_{\text {aq }} \times Q}$

The uncertainties associated with the INP concentrations are plotted in Fig. $4 \mathrm{~b}$ as vertical error bars on the $T_{50}$ values for one sample from each instrument, and the calculations are described in Section S11. The uncertainties include $1 \%$ error in $V_{\text {well,DRINCZ }}, 0.5 \%$ error in $V_{\text {well,LINDA }}$, and $8 \%$ error in

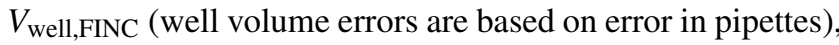
as well as an error of \pm 1 in the number of frozen wells, an error in the flow rate of the Coriolis impinger of $\pm 10 \mathrm{~L} \mathrm{~min}^{-1}$, and an error of $\pm 0.5 \mathrm{~mL}$ in the final Coriolis sample volume.

The INP concentration in the aerosol sample as a function of temperature agreed well between the instruments, with the advantage of FINC being able to achieve lower temperature measurements than DRINCZ and LINDA due to the smaller well volume (Fig. 4b, and see Sect. 4.5). The measurements 


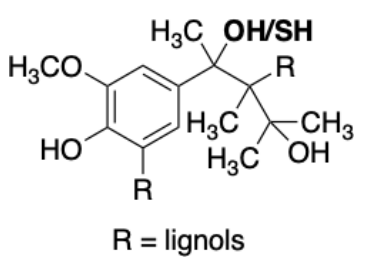

Figure 5. Example of the chemical structure of a lignin monomer known as a lignol. The commercial lignin material used in this work has a thiol group in the benzylic position instead of an alcohol group (highlighted in bold).

also fit within the range of INP concentrations per liter of air from cloud water and precipitation samples compiled by Petters and Wright (2015). Furthermore, since LINDA was part of the intercomparison study of ice nucleation instruments reported by Hiranuma et al. (2019), which used cellulose as a standard, FINC and DRINCZ are by extension expected to have representative freezing temperature ranges. These results further validate the capabilities of FINC to be used for measuring ice nuclei concentrations.

\section{Lignin as an ice nucleation standard}

We describe here the use of commercial and water-soluble lignin as a standard for intercomparing droplet freezing techniques (DFTs). Its applicability is demonstrated through the intercomparison measurements of lignin with three different DFTs (Sect. 6.2), the comparison of different batches of a commercial lignin product (Sect. 6.3), the stability of lignin solutions over time (Sect. 6.4), and the recalcitrance of lignin towards chemical and atmospheric processing (Sect. 6.5).

\subsection{Chemical composition of lignin}

Lignin is a high-molecular-weight natural polymer accounting for approximately $30 \%$ of the organic carbon present in the biosphere (Boerjan et al., 2003). It is composed of three different types of hydroxycinnamyl alcohol monomers referred to as monolignols, specifically para-coumaryl alcohol, coniferyl alcohol, and sinapyl alcohol (Faraji et al., 2018) (Fig. 5). The relative quantity of monolignols within the lignin polymer varies depending on taxa, cell type, and cell layers, as well as on the development stage of the tree, the climate, and the habitat (Boerjan et al., 2003), leading to a large number of possible permutations within the natural lignin polymer. The polymerization of monolignols occurs through a stepwise chemically controlled process linking ether bonds $(\beta-\mathrm{O}-4, \alpha-\mathrm{O}-4)$ and carbon-carbon bonds (Ralph et al., 2019). Lignin indeed constitutes a mixture of monolignols but specifically represents repeating units of known chemical functional groups such as oxygen-substituted arenes, conjugated double bonds, and alcohols. Lignin's van Krevelen diagrams, determined using high-resolution mass spectrometry, typically have $\mathrm{H}: \mathrm{C}$ ratios between 0.6 and 1.6 and $\mathrm{O}: \mathrm{C}$ ratios between 0.1 and 0.7 (Devarajan et al., 2020). These ratios are distinct from other classes of organic matter, namely carbohydrates, lipids, peptides, and tannins (Kim et al., 2003; Hockaday et al., 2009; Ohno et al., 2010; Sleighter et al., 2010). Interestingly, lignin has recently been modeled to aggregate with itself (Devarajan et al., 2020). Furthermore, the commercial lignin used in this work is a by-product of the pulp and paper industry and therefore has a reproducible chemical composition, arguably important for a standard, and a molecular weight average of $10000 \mathrm{~g} \mathrm{~mol}^{-1}$ (Fig. 5). Section 6.3 confirms this reproducibility specifically for ice nucleation. We further acknowledge that this commercial lignin contains a thiol group, which differs from atmospherically relevant monolignols yet is used here as a soluble and cheap standard for the intercomparison of DFTs (Fig. 5).

\subsection{Instrument intercomparison with lignin and IN parameterization}

The measurements on FINC, DRINCZ, and LINDA were conducted on the same day (11 July 2019) with identical lignin solutions. Specifically, one solution of $20 \mathrm{mg} \mathrm{C} \mathrm{L}^{-1}$ of lignin (of batch 1; see Sect. 6.3) diluted in background water was divided into sterile Falcon tubes and brought to each instrument.

We calculated the ice-active mass site density, the $n_{\mathrm{m}} \mathrm{val}-$ ues, for each measurement according to Eq. (5) and analogous to Eq. (3), also following Vali $(1971,2019)$ :

$n_{\mathrm{m}}(T)\left[\mathrm{mg}^{-1}\right]=-\frac{\ln [1-\mathrm{FF}(T)]}{\mathrm{TOC} \times V_{\text {well }}}$,

where TOC is the total organic carbon of the lignin solution, and $V_{\text {well }}$ is the volume inside each well ( $V_{\text {well }}$ is $30 \mu \mathrm{L}$ for FINC during the intercomparison study, $5 \mu \mathrm{L}$ for FINC during batch experiments, $50 \mu \mathrm{L}$ for DRINCZ, and $100 \mu \mathrm{L}$ for LINDA). TOC values were determined using the mass of lignin weighed and the vendor's description of carbon content $(50.13 \%)$, and these were further validated using a Shimadzu TOC analyzer with the prior pre-treatment addition of nitric acid and sulfuric acid. Uncertainties in $n_{\mathrm{m}}$ include a $1 \%$ error in TOC, $1 \%$ error in $V_{\text {well,DRINCZ }}, 0.5 \%$ error in $V_{\text {well,LINDA }}, 8 \%$ error in $V_{\text {well,FINC }}$ (well volume errors are based on error in pipettes), and finally an error of \pm 1 in the number of frozen wells. The uncertainty calculations are presented in Sect. S11 and displayed in Fig. 6 as error bars on the $T_{50}$ of one sample from each instrument.

The freezing temperatures of $20 \mathrm{mg} \mathrm{C} \mathrm{L}^{-1}$ compared well between FINC, DRINCZ, and LINDA, with overlapping $n_{m}$ traces falling within a factor of 3 (Fig. 6). Specifically, at $-14.8^{\circ} \mathrm{C}$, lignin's $n_{\mathrm{m}}$ values from the intercomparison range from 77 to $223 \mathrm{mg}^{-1}$, and at $-19.5^{\circ} \mathrm{C}$ they range from 1760 to $4560 \mathrm{mg}^{-1}$. This spread is an improvement relative to NX-illite, which has $n_{\mathrm{s}}$ values that span an order of magnitude (Fig. 4a). Moreover, the data from the intercompari- 


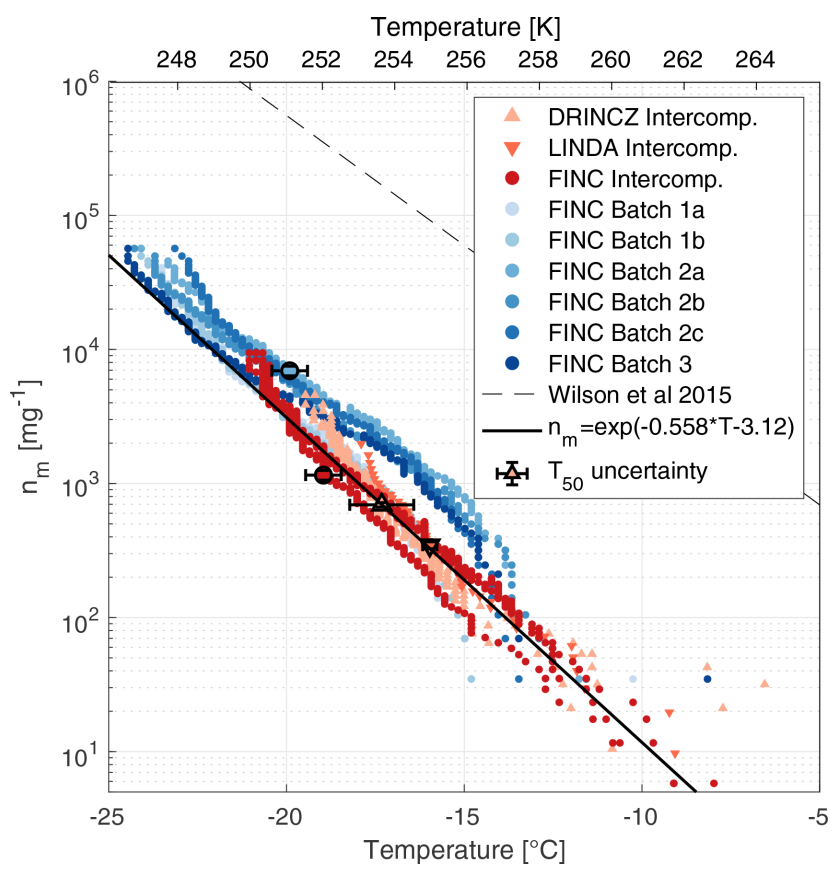

Figure 6. Ice-active mass site density $\left(n_{\mathrm{m}}\right)$ of lignin measured by FINC, DRINCZ, and LINDA. Lignin was measured during the intercomparison on FINC $(30 \mu \mathrm{L}$ well volume; three replicates; dark red dots), DRINCZ ( $50 \mu \mathrm{L}$ well volume; four replicates; orange triangles), and LINDA ( $100 \mu \mathrm{L}$ well volume; one replicate; red triangles). Additionally, different product batches of lignin were measured by FINC ( $5 \mu \mathrm{L}$ well volume; six experiments, blue dots). Note that the markers of batches $1 \mathrm{a}$ and $1 \mathrm{~b}$ are partially hidden behind the orange intercomparison markers. All lignin solutions were of concentration $20 \mathrm{mg} \mathrm{CL}^{-1}$. The black line is the empirical fit of the intercomparison data only $\left(n_{\mathrm{m}}=\exp (-0.558 \times T-3.12)\right)$. The parameterization of the sea surface microlayer organic matter from Wilson et al. (2015) is also shown (dashed lined). Error bars in the $x$ and $y$ direction are shown on the $T_{50}$ value for one sample each from DRINCZ, LINDA, and FINC batch experiments, as well as FINC intercomparison experiments (see Supplement Sect. S11 for details). Note that the $y$-direction uncertainties do not extend beyond the marker.

son were fitted to obtain a parameterization for lignin's icenucleating ability in immersion freezing, shown as the solid black line in Fig. 6. In addition, $T_{50}$ and $T_{5}$ values were $-17.5 \pm 0.9$ and $-12.4 \pm 1.3^{\circ} \mathrm{C}$, respectively. Unlike Kunert et al. (2018), who observed reproducible initial freezing temperatures with Snomax, we observe lignin's freezing temperatures to be reproducible starting at $T_{5}$ values (with $5 \%$ of wells frozen). Note that the FINC batch measurements, also shown in Fig. 6, were not included in the empirical fit to avoid over-weighting the FINC data. The fit is represented in Eq. (6), where $T$ is temperature in degrees Celsius $\left({ }^{\circ} \mathrm{C}\right)$.

$n_{\mathrm{m}}=\exp (-0.558 \times T-3.12)$

Note that this parameterization is specifically valid for lignin solutions of $20 \mathrm{mg} \mathrm{CL}^{-1}$. In fact, lignin is a macromolecule suggested to adopt different solution aggregation properties depending on its concentration (Bogler and BorduasDedekind, 2020), and thus our parameterization is exclusively for concentrations of $20 \mathrm{mg} \mathrm{C} \mathrm{L}^{-1}$, equivalent to $40 \mathrm{mg}$ of lignin per liter. For reference to other INMs, the $n_{\mathrm{m}}$ parameterization by Wilson et al. (2015) of sea surface microlayer organic matter is included (Fig. 6). While the slope is similar for both parameterizations (Fig. 6), the Wilson parameterization is interestingly 2 orders of magnitude higher. Lignin is not the most active INM in the sea surface microlayer, in sea spray, or in bioaerosols (Steinke et al., 2020), so we were therefore surprised to notice the similarity in slope. However, organic matter $n_{\mathrm{m}}$ data from several other studies are inconsistent with this slope, highlighting the difficulties in predicting the ice-nucleating ability of organic matter (BorduasDedekind et al., 2019; Pummer et al., 2015; O'Sullivan et al., 2014; McCluskey et al., 2017).

\subsection{Lignin batch comparison}

A desirable quality of a suitable ice nucleation standard is its ability to be reproducible across commercial product batches. The lignin used here is alkali low-sulfonate kraft lignin (CAS 8068-05-1, Sigma Aldrich, product code 471003). We tested the ice-nucleating ability of three different batches of this product: batch numbers 04414PE, MKCL2371, and MKCK3344 (hereafter referred to as batches 1,2, and 3, respectively). Specifications on their production dates and their carbon and sulfur contents are provided in Table S4. The $n_{\mathrm{m}}$ values, determined according to Eq. (5), of batches 2 and 3 overlapped with each other (Fig. 6). The values of batch 1 overlapped with the other batches below $-19^{\circ} \mathrm{C}$ but above $-19^{\circ} \mathrm{C}$ had fewer ice-active mass site densities (Fig. 6). Still, all batches were within 1 order of magnitude of each other and of the empirical fit from the intercomparison data (Fig. 6). These results indicate that lignin's ice-nucleating activity is reproducible across different production batches.

\subsection{Lignin solution stability}

In addition to reproducibility across product batches, another quality of a standard is its stability in solution over time towards ice nucleation. Therefore, we performed multiple FINC experiments with the same $20 \mathrm{mg} \mathrm{CL}^{-1}$ solution of lignin (using batch 2) over 4 months and found no change in ice-nucleating activity (Fig. 7), unlike for NXillite (see Sect. 5.2 and Fig. 4). We additionally performed several freezing experiments on a more concentrated solution of $200 \mathrm{mg} \mathrm{C} \mathrm{L}^{-1}$ of lignin (using batch 2) and also found no significant change in ice-nucleating activity over 8 weeks (Fig. S16). Furthermore, we tested the effect of the storage temperature of the lignin solution in the fridge and on the lab bench and found no difference (Fig. S17). This solution sta- 


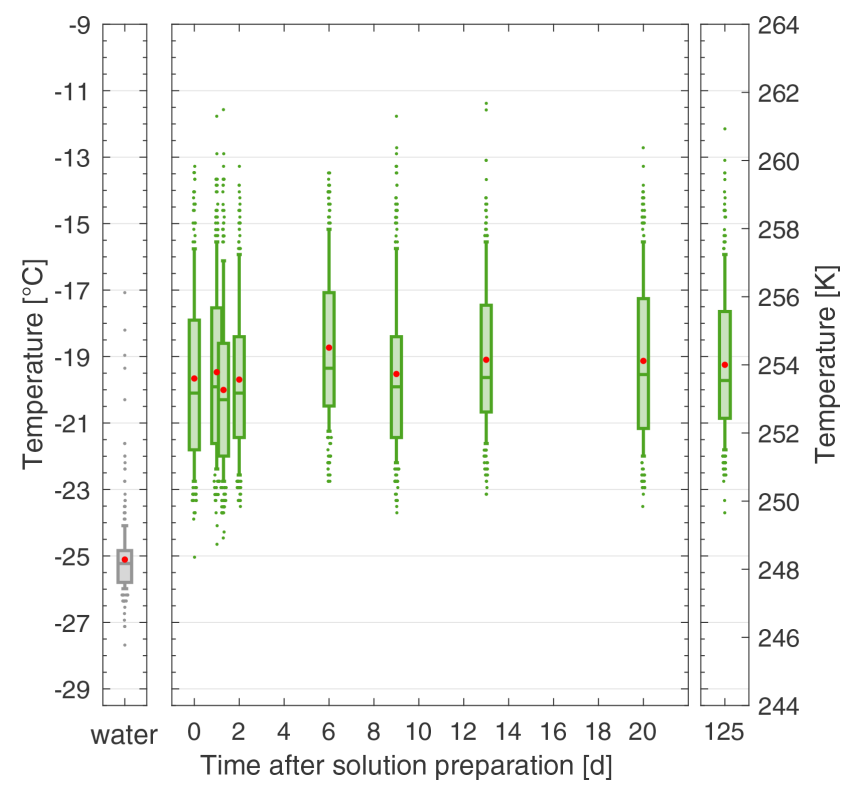

Figure 7. The solution stability of a $20 \mathrm{mg} \mathrm{C} \mathrm{L}^{-1}$ lignin solution (batch 2) over $125 \mathrm{~d}$, stored in the fridge in the dark. Each box plot represents the frozen temperatures of 288 wells; the middle line is the median $\left(T_{50}\right)$, the outer edges of the box are the 25 th and 75 th percentiles, the whiskers extend to the 10th and 90th percentiles, and the red dot is the mean. The water box plot represents the background water solution. Duplicates were taken on day 1 (overlapping box plots). All temperature measurements have an uncertainty of $\pm 0.5^{\circ} \mathrm{C}$.

bility makes lignin a complementary ice nucleation standard over NX-illite and Snomax.

\subsection{Lignin's macromolecular size and reactivity}

Lignin's recalcitrance towards atmospheric processing has recently been demonstrated by Bogler and BorduasDedekind (2020). Indeed, photochemical exposure, ozonation, heating, sonication, and hydrogen peroxide treatments had negligible effects on lignin's ice nucleation ability. Also note that the lignin recommended herein is soluble; accordingly, it passed through a $0.2 \mu \mathrm{m}$ filter without loss of ice activity but lost some activity after filtering to $0.02 \mu \mathrm{m}$ (Bogler and Borduas-Dedekind, 2020). Lignin could therefore be termed a nano-INP (O'Sullivan et al., 2015) or an INM (Pummer et al., 2015) and operationally defined as soluble (Borduas-Dedekind et al., 2019). The ability of lignin to be chemically recalcitrant further demonstrates its value as a standard for DFTs.

\section{Conclusions}

We describe herein our home-built drop Freezing Ice Nuclei Counter (FINC) to measure the ice-nucleating ability of INPs and INMs in the immersion freezing mode. FINC is a complementary instrument and part of a growing list of droplet freezing techniques (Table 1). Its capabilities include (1) simultaneously measuring three trays of 96 wells each, (2) supercooling to $T_{50}=-25.4 \pm 0.2$ with $5 \mu \mathrm{L}$ droplets with a temperature uncertainty of $\pm 0.5^{\circ} \mathrm{C}$, and (3) automated controls for running an experiment. We further explored eight different possible explanations for the nonhomogeneous freezing behavior observed in FINC and other DFTs. As part of the development and validation of FINC, we intercompared measurements with NX-illite suspensions and an ambient aerosol sample collected in Zurich with other DFTs, specifically with DRINCZ and LINDA. Additionally, we present evidence for the use of soluble lignin as a reproducible, easy to use, and commercial intercomparison standard for future ice nucleation studies in immersion freezing. Indeed, we demonstrated that solutions of $20 \mathrm{mg} \mathrm{C} \mathrm{L}^{-1}$ measured on FINC, DRINCZ, and LINDA yielded a spread of $n_{\mathrm{m}}$ values within a factor of 3 between -8 and $-25^{\circ} \mathrm{C}$. We subsequently fitted a parameterization $\left(n_{\mathrm{m}}=\exp (-0.558 \times T-3.12)\right)$ through our empirical data for further use in intercomparison and validation studies. Finally, we showed that lignin solutions are stable over several months, and their ice-nucleating activity is well reproduced across different batches of the same product, making lignin a competitive solution standard.

Code and data availability. Data sets for all data presented in figures in the text are deposited in the ETH Research Collection data repository at https://doi.org/10.3929/ethz-b-000438875 (Miller et al., 2020, last access: 6 April 2021). Necessary code for running experiments on FINC is also available upon request.

Supplement. The supplement related to this article is available online at: https://doi.org/10.5194/amt-14-3131-2021-supplement.

Author contributions. KPB and NBD designed the instrument. KPB wrote the code to operate the instrument. AJM validated the instrument. AJM, KPB, CM, and JW acquired data during the intercomparisons; NBD, AJM, and KPB wrote the paper with contributions from all authors.

Competing interests. The authors declare that they have no conflict of interest.

Acknowledgements. We acknowledge the technical help of Marco Vecellio and Michael Rösch for advice, ordering hardware, and machining structural instrument components. We also acknowledge the assistance of Max Aragón Cerecedes during the intercomparison experiment day. We thank Sophie Bogler for help with the tray washing experiments and Silvan Müller for help with the TOC 
analyzer. We are grateful to Paul DeMott and Tom Hill for reviewing our compiled list of droplet freezing techniques.

Financial support. This research was supported by the Swiss National Science Foundation (grant no. PZ00P2_179703). Furthermore, Claudia Mignani and Jörg Wieder acknowledge funding from the Swiss National Science Foundation (grant nos. 200021_169620 and 200021_17582, respectively), and Robert O. David acknowledges funding from the European Research Council (grant StG 758005).

Review statement. This paper was edited by Mingjin Tang and reviewed by three anonymous referees.

\section{References}

Ardon-Dryer, K., Levin, Z., and Lawson, R. P.: Characteristics of immersion freezing nuclei at the South Pole station in Antarctica, Atmos. Chem. Phys., 11, 4015-4024, https://doi.org/10.5194/acp-11-4015-2011, 2011.

Atkins, P. and de Paula, J.: Physical Chemistry for the Life Sciences, OUP Oxford, 619 pp., 2011.

Atkinson, J. D., Murray, B. J., Woodhouse, M. T., Whale, T. F., Baustian, K. J., Carslaw, K. S., Dobbie, S., O'Sullivan, D., and Malkin, T. L.: The Importance of Feldspar for Ice Nucleation by Mineral Dust in Mixed-Phase Clouds, Nature, 498, 355-358, https://doi.org/10.1038/nature12278, 2013.

Barry, K. R., Hill, T. C., Jentzsch, C., Moffett, B. F., Stratmann, F., and DeMott, P. J.: Pragmatic Protocols for Working Cleanly When Measuring Ice Nucleating Particles, Atmos. Res., 250, 105419, https://doi.org/10.1016/j.atmosres.2020.105419, 2021.

Beall, C. M., Stokes, M. D., Hill, T. C., DeMott, P. J., DeWald, J. T., and Prather, K. A.: Automation and heat transfer characterization of immersion mode spectroscopy for analysis of ice nucleating particles, Atmos. Meas. Tech., 10, 2613-2626, https://doi.org/10.5194/amt-10-2613-2017, 2017.

Boerjan, W., Ralph, J., and Baucher, M.: Lignin Biosynthesis, Annu. Rev. Pl. Biol., 54, 519-546, https://doi.org/10.1146/annurev.arplant.54.031902.134938, 2003.

Bogler, S. and Borduas-Dedekind, N.: Lignin's ability to nucleate ice via immersion freezing and its stability towards physicochemical treatments and atmospheric processing, Atmos. Chem. Phys., 20, 14509-14522, https://doi.org/10.5194/acp-20-145092020, 2020.

Borduas-Dedekind, N., Ossola, R., David, R. O., Boynton, L. S., Weichlinger, V., Kanji, Z. A., and McNeill, K.: Photomineralization mechanism changes the ability of dissolved organic matter to activate cloud droplets and to nucleate ice crystals, Atmos. Chem. Phys., 19, 12397-12412, https://doi.org/10.5194/acp-1912397-2019, 2019.

Brennan, K. P., David, R. O., and Borduas-Dedekind, N.: Spatial and temporal variability in the ice-nucleating ability of alpine snowmelt and extension to frozen cloud fraction, Atmos. Chem. Phys., 20, 163-180, https://doi.org/10.5194/acp-20-1632020, 2020.
Broadley, S. L., Murray, B. J., Herbert, R. J., Atkinson, J. D., Dobbie, S., Malkin, T. L., Condliffe, E., and Neve, L.: Immersion mode heterogeneous ice nucleation by an illite rich powder representative of atmospheric mineral dust, Atmos. Chem. Phys., 12, 287-307, https://doi.org/10.5194/acp-12-287-2012, 2012.

Brubaker, T., Polen, M., Cheng, P., Ekambaram, V., Somers, J., Anna, S. L., and Sullivan, R. C.: Development and Characterization of a "Store and Create" Microfluidic Device to Determine the Heterogeneous Freezing Properties of Ice Nucleating Particles, Aerosol. Sci. Technol., 54, 79-93, https://doi.org/10.1080/02786826.2019.1679349, 2020.

Brunauer, S., Emmett, P. H., and Teller, E.: Adsorption of Gases in Multimolecular Layers, J. Am. Chem. Soc., 60, 309-319, https://doi.org/10.1021/ja01269a023, 1938.

Budke, C. and Koop, T.: BINARY: an optical freezing array for assessing temperature and time dependence of heterogeneous ice nucleation, Atmos. Meas. Tech., 8, 689-703, https://doi.org/10.5194/amt-8-689-2015, 2015.

Bundke, U., Nillius, B., Jaenicke, R., Wetter, T. Klein, H., and Bingemer, $\mathrm{H}_{\text {.: }}$ The Fast Ice Nucleus Chamber FINCH, Atmos. Res., 90, 180-186, https://doi.org/10.1016/j.atmosres.2008.02.008, 2008.

Carvalho, E., Sindt, C., Verdier, A., Galan, C., O’Donoghue, L., Parks, S., and Thibaudon, M.: Performance of the Coriolis Air Sampler, a High-Volume Aerosol-Collection System for Quantification of Airborne Spores and Pollen Grains, Aerobiologia, 24, 191-201, https://doi.org/10.1007/s10453-008-9098-y, 2008.

Chen, J., Pei, X., Wang, H., Chen, J., Zhu, Y., Tang, M., and Wu, Z. Development, Characterization, and Validation of a Cold StageBased Ice Nucleation Array (PKU-INA), Atmosphere, 9, 357, https://doi.org/10.3390/atmos9090357, 2018a.

Chen, J., Wu, Z., Augustin-Bauditz, S., Grawe, S., Hartmann, M., Pei, X., Liu, Z., Ji, D., and Wex, H.: Icenucleating particle concentrations unaffected by urban air pollution in Beijing, China, Atmos. Chem. Phys., 18, 3523-3539, https://doi.org/10.5194/acp-18-3523-2018, 2018 b.

Ciesielski, P. N., Pecha, M. B., Lattanzi, A. M., Bharadwaj, V. S., Crowley, M. F., Bu, L., Vermaas, J. V., Steirer, K. X., and Crowley, M. F.: Advances in Multiscale Modeling of Lignocellulosic Biomass, ACS Sustainable Chem. Eng., 8, 3512-3531, https://doi.org/10.1021/acssuschemeng.9b07415, 2020.

Conen, F., Henne, S., Morris, C. E., and Alewell, C.: Atmospheric ice nucleators active $\geq-12{ }^{\circ} \mathrm{C}$ can be quantified on $\mathrm{PM}_{10}$ filters, Atmos. Meas. Tech., 5, 321-327, https://doi.org/10.5194/amt-5321-2012, 2012.

Conen, F., Stopelli, E., and Zimmermann, L.: Clues That Decaying Leaves Enrich Arctic Air with Ice Nucleating Particles, Atmos. Environ., 129, 91-94, https://doi.org/10.1016/j.atmosenv.2016.01.027, 2016.

Cook, F., Lord, R., Sitbon, G., Stephens, A., Rust, A., and Schwarzacher, W.: A pyroelectric thermal sensor for automated ice nucleation detection, Atmos. Meas. Tech., 13, 2785-2795, https://doi.org/10.5194/amt-13-2785-2020, 2020.

Creamean, J. M., Primm, K. M., Tolbert, M. A., Hall, E. G., Wendell, J., Jordan, A., Sheridan, P. J., Smith, J., and Schnell, R. C.: HOVERCAT: a novel aerial system for evaluation of aerosol-cloud interactions, Atmos. Meas. Tech., 11, 3969-3985, https://doi.org/10.5194/amt-11-3969-2018, 2018. 
David, R. O., Cascajo-Castresana, M., Brennan, K. P., Rösch, M., Els, N., Werz, J., Weichlinger, V., Boynton, L. S., Bogler, S., Borduas-Dedekind, N., Marcolli, C., and Kanji, Z. A.: Development of the DRoplet Ice Nuclei Counter Zurich (DRINCZ): validation and application to field-collected snow samples, Atmos. Meas. Tech., 12, 6865-6888, https://doi.org/10.5194/amt12-6865-2019, 2019.

de Boer, G., Morrison, H., Shupe, M. D., and Hildner, R.: Evidence of Liquid Dependent Ice Nucleation in High-Latitude Stratiform Clouds from Surface Remote Sensors, Geophys. Res. Lett., 38, L01803, https://doi.org/10.1029/2010GL046016, 2011.

Devarajan, D., Liang, L., Gu, B., Brooks, S. C., Parks, J. M., and Smith, J. C.: Molecular Dynamics Simulation of the Structures, Dynamics, and Aggregation of Dissolved Organic Matter, Environ. Sci. Technol., 54, 13527-13537, https://doi.org/10.1021/acs.est.0c01176, 2020.

Diao, Y., Myerson, A. S., Hatton, T. A., and Trout, B. L.: Surface Design for Controlled Crystallization: The Role of Surface Chemistry and Nanoscale Pores in Heterogeneous Nucleation, Langmuir, 27, 5324-5334, https://doi.org/10.1021/la104351k, 2011.

Diehl, K., Debertshäuser, M., Eppers, O., Schmithüsen, H., Mitra, S. K., and Borrmann, S.: Particle surface area dependence of mineral dust in immersion freezing mode: investigations with freely suspended drops in an acoustic levitator and a vertical wind tunnel, Atmos. Chem. Phys., 14, 12343-12355, https://doi.org/10.5194/acp-14-12343-2014, 2014.

Dymarska, M., Murray, B. J., Sun, L., Eastwood, M. L., Knopf, D. A., and Bertram, A. K.: Deposition Ice Nucleation on Soot at Temperatures Relevant for the Lower Troposphere, J. Geophys. Res.-Atmos., 111, D04204, https://doi.org/10.1029/2005JD006627, 2006.

Faraji, M., Fonseca, L. L., Escamilla-Treviño, L., Barros-Rios, J., Engle, N., Yang, Z. K., Tschaplinski, T. J., Dixon, R. A., and Voit, E. O.: Mathematical Models of Lignin Biosynthesis, Biotechn. Biofuels, 11, 34, https://doi.org/10.1186/s13068-0181028-9, 2018.

Felgitsch, L., Baloh, P., Burkart, J., Mayr, M., Momken, M. E., Seifried, T. M., Winkler, P., Schmale III, D. G., and Grothe, H.: Birch leaves and branches as a source of icenucleating macromolecules, Atmos. Chem. Phys., 18, 1606316079, https://doi.org/10.5194/acp-18-16063-2018, 2018.

Gómez-Domenech, M., García-Mozo, H., Alcázar, P., Brandao, R., Caeiro, E., Munhoz, V., and Galán, C.: Evaluation of the Efficiency of the Coriolis Air Sampler for Pollen Detection in South Europe, Aerobiologia, 26, 149-155, https://doi.org/10.1007/s10453-009-9152-4, 2010.

Gute, E. and Abbatt, J. P. D.: Ice Nucleating Behavior of Different Tree Pollen in the Immersion Mode, Atmos. Environ., 231, 117488, https://doi.org/10.1016/j.atmosenv.2020.117488, 2020.

Harkin, J. M.: Lignin and Its Uses, Research Note FPL-0206, U.S. Department of Agriculture, Forest Service, Forest Products, Laboratory, Madison, Wisconsin, 10 pp., 1969.

Harrison, A. D., Whale, T. F., Rutledge, R., Lamb, S., Tarn, M. D., Porter, G. C. E., Adams, M. P., McQuaid, J. B., Morris, G. J., and Murray, B. J.: An instrument for quantifying heterogeneous ice nucleation in multiwell plates using infrared emissions to detect freezing, Atmos. Meas. Tech., 11, 5629-5641, https://doi.org/10.5194/amt-11-5629-2018, 2018.
Häusler, T., Witek, L., Felgitsch, L., Hitzenberger, R., and Grothe, H.: Freezing on a Chip - A New Approach to Determine Heterogeneous Ice Nucleation of Micrometer-Sized Water Droplets, Atmosphere, 9, 140, https://doi.org/10.3390/atmos9040140, 2018.

Heymsfield, A. J., Schmitt, C., Chen, C.-C.-J., Bansemer, A., Gettelman, A., Field, P. R., and Liu, C.: Contributions of the Liquid and Ice Phases to Global Surface Precipitation: Observations and Global Climate Modeling, J. Atmos. Sci., 77, 2629-2648, https://doi.org/10.1175/JAS-D-19-0352.1, 2020.

Hill, T. C. J., Moffett, B. F., DeMott, P. J., Georgakopoulos, D. G., Stump, W. L., and Franc, G. D.: Measurement of Ice Nucleation-Active Bacteria on Plants and in Precipitation by Quantitative PCR, Appl. Environ. Microbiol., 80, 1256-1267, https://doi.org/10.1128/AEM.02967-13, 2014.

Hiranuma, N., Augustin-Bauditz, S., Bingemer, H., Budke, C., Curtius, J., Danielczok, A., Diehl, K., Dreischmeier, K., Ebert, M., Frank, F., Hoffmann, N., Kandler, K., Kiselev, A., Koop, T., Leisner, T., Möhler, O., Nillius, B., Peckhaus, A., Rose, D., Weinbruch, S., Wex, H., Boose, Y., DeMott, P. J., Hader, J. D., Hill, T. C. J., Kanji, Z. A., Kulkarni, G., Levin, E. J. T., McCluskey, C. S., Murakami, M., Murray, B. J., Niedermeier, D., Petters, M. D., O’Sullivan, D., Saito, A., Schill, G. P., Tajiri, T., Tolbert, M. A., Welti, A., Whale, T. F., Wright, T. P., and Yamashita, K.: A comprehensive laboratory study on the immersion freezing behavior of illite NX particles: a comparison of 17 ice nucleation measurement techniques, Atmos. Chem. Phys., 15, 2489-2518, https://doi.org/10.5194/acp-15-2489-2015, 2015a.

Hiranuma, N., Möhler, O., Yamashita, K., Tajiri, T., Saito, A., Kiselev, A., Hoffmann, N., Hoose, C., Jantsch, E., Koop, T., and Murakami, M.: Ice Nucleation by Cellulose and Its Potential Contribution to Ice Formation in Clouds, Nat. Geosci., 8, 273-277, https://doi.org/10.1038/ngeo2374, 2015 b.

Hiranuma, N., Adachi, K., Bell, D. M., Belosi, F., Beydoun, H., Bhaduri, B., Bingemer, H., Budke, C., Clemen, H.-C., Conen, F., Cory, K. M., Curtius, J., DeMott, P. J., Eppers, O., Grawe, S., Hartmann, S., Hoffmann, N., Höhler, K., Jantsch, E., Kiselev, A., Koop, T., Kulkarni, G., Mayer, A., Murakami, M., Murray, B. J., Nicosia, A., Petters, M. D., Piazza, M., Polen, M., Reicher, N., Rudich, Y., Saito, A., Santachiara, G., Schiebel, T., Schill, G P., Schneider, J., Segev, L., Stopelli, E., Sullivan, R. C., Suski, K., Szakáll, M., Tajiri, T., Taylor, H., Tobo, Y., Ullrich, R., Weber, D., Wex, H., Whale, T. F., Whiteside, C. L., Yamashita, K., Zelenyuk, A., and Möhler, O.: A comprehensive characterization of ice nucleation by three different types of cellulose particles immersed in water, Atmos. Chem. Phys., 19, 4823-4849, https://doi.org/10.5194/acp-19-4823-2019, 2019.

Hockaday, W. C., Purcell, J. M., Marshall, A. G., Baldock, J. A., and Hatcher, P. G.: Electrospray and Photoionization Mass Spectrometry for the Characterization of Organic Matter in Natural Waters: A Qualitative Assessment, Limnol. Oceanogr., 7, 81-95, https://doi.org/10.4319/lom.2009.7.81, 2009.

Hoose, C., Kristjánsson, J. E., Chen, J.-P., and Hazra, A.: A Classical-Theory-Based Parameterization of Heterogeneous Ice Nucleation by Mineral Dust, Soot, and Biological Particles in a Global Climate Model, J. Atmos. Sci., 67, 2483-2503, https://doi.org/10.1175/2010JAS3425.1, 2010.

Ickes, L., Welti, A., Hoose, C., and Lohmann, U.: Classical Nucleation Theory of Homogeneous Freezing of Water: Thermo- 
dynamic and Kinetic Parameters, Phys. Chem. Chem. Phys., 17, 5514-5537, https://doi.org/10.1039/C4CP04184D, 2015.

IPCC: Climate Change 2013: The Physical Science Basis. Contribution of Working Group I to the Fifth Assessment Report of the Intergovernmental Panel on Climate Change., Cambridge University Press, Cambridge, United Kingdom and New York, NY, USA, 1538 pp., 2013.

Kanji, Z. A., Ladino, L. A., Wex, H., Boose, Y., BurkertKohn, M., Cziczo, D. J., and Krämer, M.: Overview of Ice Nucleating Particles, Meteorol. Monogr., 58, 133, https://doi.org/10.1175/AMSMONOGRAPHS-D-16-0006.1, 2017.

Kim, S., Kramer, R. W., and Hatcher, P. G.: Graphical Method for Analysis of Ultrahigh-Resolution Broadband Mass Spectra of Natural Organic Matter, the Van Krevelen Diagram, Anal. Chem., 75, 5336-5344, https://doi.org/10.1021/ac034415p, 2003.

Koop, T. and Murray, B. J.: A Physically Constrained Classical Description of the Homogeneous Nucleation of Ice in Water, J. Chem. Phys., 145, 211915, https://doi.org/10.1063/1.4962355, 2016.

Koop, T., Kapilashrami, A., Molina, L. T., and Molina, M. J.: Phase Transitions of Sea-Salt/Water Mixtures at Low Temperatures: Implications for Ozone Chemistry in the Polar Marine Boundary Layer, J. Geophys. Res.-Atmos., 105, 26393-26402, https://doi.org/10.1029/2000JD900413, 2000a.

Koop, T., Luo, B., Tsias, A., and Peter, T.: Water Activity as the Determinant for Homogeneous Ice Nucleation in Aqueous Solutions, Nature, 406, 611-614, https://doi.org/10.1038/35020537, 2000b.

Kumar, A., Marcolli, C., and Peter, T.: Ice nucleation activity of silicates and aluminosilicates in pure water and aqueous solutions - Part 3: Aluminosilicates, Atmos. Chem. Phys., 19, 6059-6084, https://doi.org/10.5194/acp-19-6059-2019, 2019.

Kunert, A. T., Lamneck, M., Helleis, F., Pöschl, U., Pöhlker, M. L., and Fröhlich-Nowoisky, J.: Twin-plate Ice Nucleation Assay (TINA) with infrared detection for high-throughput droplet freezing experiments with biological ice nuclei in laboratory and field samples, Atmos. Meas. Tech., 11, 6327-6337, https://doi.org/10.5194/amt-11-6327-2018, 2018.

Kunert, A. T., Pöhlker, M. L., Tang, K., Krevert, C. S., Wieder, C., Speth, K. R., Hanson, L. E., Morris, C. E., Schmale III, D. G., Pöschl, U., and Fröhlich-Nowoisky, J.: Macromolecular fungal ice nuclei in Fusarium: effects of physical and chemical processing, Biogeosciences, 16, 4647-4659, https://doi.org/10.5194/bg16-4647-2019, 2019.

Li, K., Xu, S., Shi, W., He, M., Li, H., Li, S., Zhou, X., Wang, J., and Song, Y.: Investigating the Effects of Solid Surfaces on Ice Nucleation, Langmuir, 28, 10749-10754, https://doi.org/10.1021/la3014915, 2012.

Lloyd, G., Choularton, T., Bower, K., Crosier, J., Gallagher, M., Flynn, M., Dorsey, J., Liu, D., Taylor, J. W., Schlenczek, O., Fugal, J., Borrmann, S., Cotton, R., Field, P., and Blyth, A.: Small ice particles at slightly supercooled temperatures in tropical maritime convection, Atmos. Chem. Phys., 20, 3895-3904, https://doi.org/10.5194/acp-20-3895-2020, 2020.

Lohmann, U., Luond, F., and Mahrt, F.: An Introduction to Clouds: From the Microscale to Climate, Cambridge University Press, Cambridge, https://doi.org/10.1017/CBO9781139087513, 2016.
Marcolli, C.: Ice Nucleation Triggered by Negative Pressure, Sci. Rep., 7, 16634, https://doi.org/10.1038/s41598-017-167873, 2017.

Marcolli, C.: Technical note: Fundamental aspects of ice nucleation via pore condensation and freezing including Laplace pressure and growth into macroscopic ice, Atmos. Chem. Phys., 20, 32093230, https://doi.org/10.5194/acp-20-3209-2020, 2020.

Mason, R. H., Chou, C., McCluskey, C. S., Levin, E. J. T., Schiller, C. L., Hill, T. C. J., Huffman, J. A., DeMott, P. J., and Bertram, A. K.: The micro-orifice uniform deposit impactordroplet freezing technique (MOUDI-DFT) for measuring concentrations of ice nucleating particles as a function of size: improvements and initial validation, Atmos. Meas. Tech., 8, 24492462, https://doi.org/10.5194/amt-8-2449-2015, 2015.

McCluskey, C. S., Hill, T. C. J., Malfatti, F., Sultana, C. M., Lee, C., Santander, M. V., Beall, C. M., Moore, K. A., Cornwell, G. C., Collins, D. B., Prather, K. A., Jayarathne, T., Stone, E. A., Azam, F., Kreidenweis, S. M., and DeMott, P. J.: A Dynamic Link between Ice Nucleating Particles Released in Nascent Sea Spray Aerosol and Oceanic Biological Activity during Two Mesocosm Experiments, J. Atmos. Sci., 74, 151-166, https://doi.org/10.1175/JAS-D-16-0087.1, 2017.

Mignani, C., Creamean, J. M., Zimmermann, L., Alewell, C., and Conen, F.: New type of evidence for secondary ice formation at around $-15^{\circ} \mathrm{C}$ in mixed-phase clouds, Atmos. Chem. Phys., 19, 877-886, https://doi.org/10.5194/acp-19-877-2019, 2019.

Miller, A. J., Brennan, K. P., Mignani, C., Wieder, J., David, R. O., and Borduas-Dedekind, N.: Development of the drop Freezing Ice Nuclei Counter (FINC), intercomparison of drop freezing instruments, and use of soluble lignin as an atmospheric ice nucleation standard, Dataset in ETH Zurich Research Collection, https://doi.org/10.3929/ethz-b-000438875, 2020.

Morris, C. E., Georgakopoulos, D. G., and Sands, D. C.: Ice Nucleation Active Bacteria and Their Potential Role in Precipitation, Journal de Physique IV (Proceedings), 121, 87-103, https://doi.org/10.1051/jp4:2004121004, 2004.

Murray, B. J., Broadley, S. L., Wilson, T. W., Bull, S. J., Wills, R. H., Christenson, H. K., and Murray, E. J.: Kinetics of the Homogeneous Freezing of Water, Phys. Chem. Chem. Phys., 12, 10380, https://doi.org/10.1039/c003297b, 2010.

Murray, B. J., O'Sullivan, D., Atkinson, J. D., and Webb, M. E.: Ice Nucleation by Particles Immersed in Supercooled Cloud Droplets, Chem. Soc. Rev., 41, 6519-6554, https://doi.org/10.1039/c2cs35200a, 2012.

Murray, B. J., Carslaw, K. S., and Field, P. R.: Opinion: Cloud-phase climate feedback and the importance of ice-nucleating particles, Atmos. Chem. Phys., 21, 665-679, https://doi.org/10.5194/acp21-665-2021, 2021.

Myers-Pigg, A. N., Griffin, R. J., Louchouarn, P., Norwood, M. J., Sterne, A., and Cevik, B. K.: Signatures of Biomass Burning Aerosols in the Plume of a Saltmarsh Wildfire in South Texas, Environ. Sci. Technol., 50, 9308-9314, https://doi.org/10.1021/acs.est.6b02132, 2016.

O, K.-T. and Wood, R.: Exploring an approximation for the homogeneous freezing temperature of water droplets, Atmos. Chem. Phys., 16, 7239-7249, https://doi.org/10.5194/acp-167239-2016, 2016.

Ohno, T., He, Z., Sleighter, R. L., Honeycutt, C. W., and Hatcher, P. G.: Ultrahigh Resolution Mass Spectrometry and Indicator 
Species Analysis to Identify Marker Components of Soil- and Plant Biomass-Derived Organic Matter Fractions, Environ. Sci. Technol., 44, 8594-8600, https://doi.org/10.1021/es101089t, 2010.

O'Sullivan, D., Murray, B. J., Malkin, T. L., Whale, T. F., Umo, N. S., Atkinson, J. D., Price, H. C., Baustian, K. J., Browse, J., and Webb, M. E.: Ice nucleation by fertile soil dusts: relative importance of mineral and biogenic components, Atmos. Chem. Phys., 14, 1853-1867, https://doi.org/10.5194/acp-141853-2014, 2014.

O'Sullivan, D., Murray, B. J., Ross, J. F., Whale, T. F., Price, H. C., Atkinson, J. D., Umo, N. S., and Webb, M. E.: The Relevance of Nanoscale Biological Fragments for Ice Nucleation in Clouds, Sci. Rep., 5, 8082, https://doi.org/10.1038/srep08082, 2015.

Peckhaus, A., Kiselev, A., Hiron, T., Ebert, M., and Leisner, T.: A comparative study of $\mathrm{K}$-rich and $\mathrm{Na} / \mathrm{Ca}$-rich feldspar icenucleating particles in a nanoliter droplet freezing assay, Atmos. Chem. Phys., 16, 11477-11496, https://doi.org/10.5194/acp-1611477-2016, 2016.

Perkins, R. J., Gillette, S. M., Hill, T. C. J., and DeMott, P. J.: The Labile Nature of Ice Nucleation by Arizona Test Dust, ACS Earth Space Chem., 4, 133-141, https://doi.org/10.1021/acsearthspacechem.9b00304, 2020.

Petters, M. D. and Wright, T. P.: Revisiting Ice Nucleation from Precipitation Samples, Geophys. Res. Lett., 42, 8758-8766, https://doi.org/10.1002/2015GL065733, 2015.

Polen, M., Lawlis, E., and Sullivan, R. C.: The Unstable Ice Nucleation Properties of Snomax, Bacterial Particles, J. Geophys. Res.-Atmos., 121, 11666-11678, https://doi.org/10.1002/2016JD025251, 2016.

Polen, M., Brubaker, T., Somers, J., and Sullivan, R. C.: Cleaning up our water: reducing interferences from nonhomogeneous freezing of "pure" water in droplet freezing assays of ice-nucleating particles, Atmos. Meas. Tech., 11, 5315-5334, https://doi.org/10.5194/amt-11-5315-2018, 2018.

Price, H. C., Baustian, K. J., McQuaid, J. B., Blyth, A., Bower, K. N., Choularton, T., Cotton, R. J., Cui, Z., Field, P. R., Gallagher, M., Hawker, R., Merrington, A., Miltenberger, A., Iii, R. R. N., Parker, S. T., Rosenberg, P. D., Taylor, J. W., Trembath, J., Vergara-Temprado, J., Whale, T. F., Wilson, T. W., Young, G., and Murray, B. J.: Atmospheric Ice-Nucleating Particles in the Dusty Tropical Atlantic, J. Geophys. Res.-Atmos., 123, 21752193, https://doi.org/10.1002/2017JD027560, 2018.

Pummer, B. G., Bauer, H., Bernardi, J., Bleicher, S., and Grothe, H.: Suspendable macromolecules are responsible for ice nucleation activity of birch and conifer pollen, Atmos. Chem. Phys., 12, 2541-2550, https://doi.org/10.5194/acp-12-2541-2012, 2012.

Pummer, B. G., Budke, C., Augustin-Bauditz, S., Niedermeier, D., Felgitsch, L., Kampf, C. J., Huber, R. G., Liedl, K. R., Loerting, T., Moschen, T., Schauperl, M., Tollinger, M., Morris, C. E., Wex, H., Grothe, H., Pöschl, U., Koop, T., and Fröhlich-Nowoisky, J.: Ice nucleation by watersoluble macromolecules, Atmos. Chem. Phys., 15, 4077-4091, https://doi.org/10.5194/acp-15-4077-2015, 2015.

Ralph, J., Lapierre, C., and Boerjan, W.: Lignin Structure and Its Engineering, Current Opinion in Biotechnology, 56, 240-249, https://doi.org/10.1016/j.copbio.2019.02.019, 2019.

Reicher, N., Segev, L., and Rudich, Y.: The WeIzmann Supercooled Droplets Observation on a Microarray (WISDOM) and application for ambient dust, Atmos. Meas. Tech., 11, 233-248, https://doi.org/10.5194/amt-11-233-2018, 2018.

Richard, C., Martin, J.-G., and Pouleur, S.: Ice Nucleation Activity Identified in Some Phytopathogenic Fusarium Species, Phyto, 77, 83-92, https://doi.org/10.7202/706104ar, 1996.

Riechers, B., Wittbracht, F., Hütten, A., and Koop, T.: The Homogeneous Ice Nucleation Rate of Water Droplets Produced in a Microfluidic Device and the Role of Temperature Uncertainty, Phys. Chem. Chem. Phys., 15, 5873-5887, https://doi.org/10.1039/C3CP42437E, 2013.

Rogers, D. C.: Development of a Continuous Flow Thermal Gradient Diffusion Chamber for Ice Nucleation Studies, Atmos. Res., 22, 149-181, https://doi.org/10.1016/01698095(88)90005-1, 1988.

Salcedo, D., Molina, L. T., and Molina, M. J.: Nucleation Rates of Nitric Acid Dihydrate in 1:2 $\mathrm{HNO} 3 / \mathrm{H} 2 \mathrm{O}$ Solutions at Stratospheric Temperatures, Geophys. Res. Lett., 27, 193-196, https://doi.org/10.1029/1999GL010991, 2000.

Schiebel, T.: Ice Nucleation Activity of Soil Dust Aerosols, $\mathrm{PhD}$ thesis, Karlsruhe Institute of Technology, Karlsruhe, https://doi.org/10.5445/IR/1000076327, 2017.

Shakya, K. M., Louchouarn, P., and Griffin, R. J.: LigninDerived Phenols in Houston Aerosols: Implications for Natural Background Sources, Environ. Sci. Technol., 45, 8268-8275, https://doi.org/10.1021/es201668y, 2011.

Sleighter, R. L., Liu, Z., Xue, J., and Hatcher, P. G.: Multivariate Statistical Approaches for the Characterization of Dissolved Organic Matter Analyzed by Ultrahigh Resolution Mass Spectrometry, Environ. Sci. Technol., 44, 7576-7582, https://doi.org/10.1021/es1002204, 2010.

Stan, C. A., Schneider, G. F., Shevkoplyas, S. S., Hashimoto, M., Ibanescu, M., Wiley, B. J., and Whitesides, G. M.: A Microfluidic Apparatus for the Study of Ice Nucleation in Supercooled Water Drops, Lab Chip, 9, 2293-2305, https://doi.org/10.1039/B906198C, 2009.

Steinke, I., Hiranuma, N., Funk, R., Höhler, K., Tüllmann, N., Umo, N. S., Weidler, P. G., Möhler, O., and Leisner, T.: Complex plantderived organic aerosol as ice-nucleating particles - more than the sums of their parts?, Atmos. Chem. Phys., 20, 11387-11397, https://doi.org/10.5194/acp-20-11387-2020, 2020.

Stopelli, E., Conen, F., Zimmermann, L., Alewell, C., and Morris, C. E.: Freezing nucleation apparatus puts new slant on study of biological ice nucleators in precipitation, Atmos. Meas. Tech., 7, 129-134, https://doi.org/10.5194/amt-7-129-2014, 2014.

Storelvmo, T.: Aerosol Effects on Climate via Mixed-Phase and Ice Clouds, Annu. Rev. Earth Planet. Sci., 45, 199-222, https://doi.org/10.1146/annurev-earth-060115-012240, 2017.

Suski, K. J., Hill, T. C. J., Levin, E. J. T., Miller, A., DeMott, P. J., and Kreidenweis, S. M.: Agricultural harvesting emissions of ice-nucleating particles, Atmos. Chem. Phys., 18, 13755-13771, https://doi.org/10.5194/acp-18-13755-2018, 2018.

Tarn, M. D., Sikora, S. N. F., Porter, G. C. E., O'Sullivan, D., Adams, M., Whale, T. F., Harrison, A. D., VergaraTemprado, J., Wilson, T. W., Shim, J.-u., and Murray, B. J.: The Study of Atmospheric Ice-Nucleating Particles via Microfluidically Generated Droplets, Microfluid Nanofluid, 22, 52, https://doi.org/10.1007/s10404-018-2069-x, 2018.

Tarn, M. D., Sikora, S. N. F., Porter, G. C. E., Wyld, B. V., Alayof, M., Reicher, N., Harrison, A. D., Rudich, Y., Shim, J.- 
U., and Murray, B. J.: On-Chip Analysis of Atmospheric IceNucleating Particles in Continuous Flow, Lab Chip, 2889-2910, https://doi.org/10.1039/D0LC00251H, 2020.

Tobo, Y.: An Improved Approach for Measuring Immersion Freezing in Large Droplets over a Wide Temperature Range, Sci. Rep., 6, 32930, https://doi.org/10.1038/srep32930, 2016.

Vali, G.: Quantitative Evaluation of Experimental Results an the Heterogeneous Freezing Nucleation of Supercooled Liquids, J. Atmos. Sci., 28, 402-409, https://doi.org/10.1175/15200469(1971)028<0402:QEOERA>2.0.CO;2, 1971.

Vali, G.: Principles of Ice Nucleation, in: Biological Ice Nucleation and Its Applications, edited by Lee, R. E., Warren, G. J., and Gusta, L. V., The American Phytopathological Society, St. Paul, Minnesota, USA, 1-39, 1995.

Vali, G.: Revisiting the differential freezing nucleus spectra derived from drop-freezing experiments: methods of calculation, applications, and confidence limits, Atmos. Meas. Tech., 12, 12191231, https://doi.org/10.5194/amt-12-1219-2019, 2019.

Vali, G. and Stansbury, E. J.: Time-Dependent Characteristics of the Heterogeneous Nucleation of Ice, Can. J. Phys., 44, 477-502, https://doi.org/10.1139/p66-044, 1966.

Vali, G., DeMott, P. J., Möhler, O., and Whale, T. F.: Technical Note: A proposal for ice nucleation terminology, Atmos. Chem. Phys., 15, 10263-10270, https://doi.org/10.5194/acp-15-102632015, 2015.

Wang, P. K.: Physics and Dynamics of Clouds and Precipitation, Cambridge University Press, Cambridge, https://doi.org/10.1017/CBO9780511794285, 2013.

Weng, L., Tessier, S. N., Smith, K., Edd, J. F., Stott, S. L., and Toner, M.: Bacterial Ice Nucleation in Monodisperse D2O and $\mathrm{H}_{2} \mathrm{O}$-in-Oil Emulsions, Langmuir, 32, 9229-9236, https://doi.org/10.1021/acs.langmuir.6b02212, 2016.

Westbrook, C. D. and Illingworth, A. J.: The Formation of Ice in a Long-Lived Supercooled Layer Cloud, Q. J. Roy. Meteor. Soc., 139, 2209-2221, https://doi.org/10.1002/qj.2096, 2013.
Wex, H., Augustin-Bauditz, S., Boose, Y., Budke, C., Curtius, J., Diehl, K., Dreyer, A., Frank, F., Hartmann, S., Hiranuma, N., Jantsch, E., Kanji, Z. A., Kiselev, A., Koop, T., Möhler, O., Niedermeier, D., Nillius, B., Rösch, M., Rose, D., Schmidt, C., Steinke, I., and Stratmann, F.: Intercomparing different devices for the investigation of ice nucleating particles using Snomax $^{\circledR}$ as test substance, Atmos. Chem. Phys., 15, 14631485, https://doi.org/10.5194/acp-15-1463-2015, 2015.

Whale, T. F., Murray, B. J., O’Sullivan, D., Wilson, T. W., Umo, N. S., Baustian, K. J., Atkinson, J. D., Workneh, D. A., and Morris, G. J.: A technique for quantifying heterogeneous ice nucleation in microlitre supercooled water droplets, Atmos. Meas. Tech., 8, 2437-2447, https://doi.org/10.5194/amt-8-2437-2015, 2015.

Wilson, T. W., Ladino, L. A., Alpert, P. A., Breckels, M. N., Brooks, I. M., Browse, J., Burrows, S. M., Carslaw, K. S., Huffman, J. A., Judd, C., Kilthau, W. P., Mason, R. H., McFiggans, G., Miller, L. A., Najera, J. J., Polishchuk, E., Rae, S., Schiller, C. L., Si, M., Temprado, J. V., Whale, T. F., Wong, J. P. S., Wurl, O., Yakobi-Hancock, J., Abbatt, J. P. D., Aller, J. Y., Bertram, A. K., Knopf, D. A., and Murray, B. J.: A Marine Biogenic Source of Atmospheric Ice-Nucleating Particles, Nature, 525, 234-238, https://doi.org/10.1038/nature14986, 2015.

Wright, T. P. and Petters, M. D.: The Role of Time in Heterogeneous Freezing Nucleation, J. Geophys. Res. Atmos., 118, 3731-3743, https://doi.org/10.1002/jgrd.50365, 2013.

Wright, T. P., Petters, M. D., Hader, J. D., Morton, T., and Holder, A. L.: Minimal Cooling Rate Dependence of Ice Nuclei Activity in the Immersion Mode, J. Geophys. Res.-Atmos., 118, 1053510543, https://doi.org/10.1002/jgrd.50810, 2013.

Zaragotas, D., Liolios, N. T., and Anastassopoulos, E.: Supercooling, Ice Nucleation and Crystal Growth: A Systematic Study in Plant Samples, Cryobiology, 72, 239-243, https://doi.org/10.1016/j.cryobiol.2016.03.012, 2016.

Zhao, B., Wang, Y., Gu, Y., Liou, K.-N., Jiang, J. H., Fan, J., Liu, X., Huang, L., and Yung, Y. L.: Ice Nucleation by Aerosols from Anthropogenic Pollution, Nat. Geosci., 12, 602607, https://doi.org/10.1038/s41561-019-0389-4, 2019. 